\title{
Prosecution of International Crimes - a Historical and Empirical Overview
}

\author{
JOSEPH RIKHOF*
}

\section{Introduction}

In general, both the development of the parameters of law dealing with international crimes and the application of this law by both international and national institutions have known historical ebbs and flows. A major impetus was received after the Second World War until about 1950 after which very little happened until the mid-nineties even though conflicts in which international crimes occurred continued unabated during the second half of the twentieth century.

Most of the law of war crimes and crimes against humanity was developed in the immediate aftermath of the Second World War and consisted of the instruments setting up the two international military tribunals in Nuremberg and Tokyo, the legislative authority enabling domestic courts to deal with war criminals in Europe and Asia, the

Senior Counsel, Manager of the Law, Crimes against Humanity and War Crimes Section, Department of Justice and Part-time Professor, International Criminal Law, University of Ottawa. The opinions expressed in this article are of the author and do not necessarily represent the positions of the Department of Justice or the Government of Canada. 
caselaw developed by these tribunals and courts, ${ }^{1}$ the adoption of the 1948 Genocide Convention and the passing of the Geneva Conventions which regulated the conduct of war, including its violations. ${ }^{2}$ Virtually all the important principles for this area of law can be traced back to this time period with some other important cases, such as the Menten case in the Netherlands, ${ }^{3}$ the Barbie, Papon and Touvier cases in France ${ }^{4}$ and the Eichman trial in Israel ${ }^{5}$ adding refinements to those principles. When international criminal law

1 The most important cases have been described in a variety of law reports; the proceedings and the verbatim judgments of the Military Tribunals in Nuremberg have been reported very extensively in the 15 volumes of the Trials of War Criminals before the Nuernberg Military Tribunals, the so-called Green Series (see http://nuremberg.law.harvard.edu/ php/docs_swi.php?DI=1\&text=nur_13tr and http://www.phdn.org/archives/www. mazal.org/NMT-HOME.htm) (Unless specified, all links have been checked 15/12/14) There has also been the Law Reports of Trials of War Criminals for all proceedings including the Nuremberg Tribunals, which is a 15 volume compilation of summaries and case comments of important decisions selected and prepared by the United Nations War Crimes Commission (see http://www.loc.gov/rr/frd/Military_Law/law-reports-trials-war-criminals.html and http://web. archive.org/web/20131212211059/http://www.ess.uwe.ac.uk/genocide/war_criminals.htm). The judgment of the Nuremberg International Military Tribunal is reported in Volume 22 of the Trial of the Major War Criminals before the International Military Tribunal, Nuremberg, 14 November 1945 - 1 October 1946 which was published at Nuremberg in 1949 and is also known as the Blue Series (see http://avalon.law.yale.edu/subject_menus/imt.asp\#proc). There is also some reporting of war crimes trials in Annual Digest and Reports of Public International Law Cases, which changed its name in 1950 to International Law Reports.

2 There are four Geneva Conventions: Geneva Convention for the Amelioration of the Condition of the Wounded and Sick in Armed Forces in the Field (Geneva I); Geneva Convention for the Amelioration of the Condition of Wounded, Sick and Shipwrecked Members of Armed Forces at Sea (Geneva II); Geneva Convention relative to the Treatment of Prisoners of War (Geneva III); Geneva Convention relative to the Protection of Civilian Persons in Time of War (Geneva IV). The war crimes provisions of the 1949 Geneva Conventions have been supplemented by the 1977 Additional Protocol I, articles 11 and 85. For a discussion of the post WWII caselaw see Rikhof, War Crimes, Crimes against Humanity and Immigration Law, 19(2) Immigration Law Reporter (1993) p. 18, at 30-46.

375 International Law Reports (1987), p. 331ff.

4 See 78 International Law Reports (1988), p. 123 for the Barbie case; http://www.trial-ch.org/en/ trial-watch/profile/db/facts/maurice_papon_188.html for the Papon case and http://www.trialch.org/en/trial-watch/profile/db/facts/paul_touvier_124.html for the Touvier case.

536 International Law Reports p. 1. 
was examined by Canadian, ${ }^{6}$ Australian ${ }^{7}$ and British criminal courts ${ }^{8}$ in the eighties and nineties, a direct link was made between the post-WWII law and the cases before them. This was not only done because the persons who had been investigated by the Canadian, British and Australian governments had committed their acts during the Second World War but also because there was no new law to speak of in the interim. However, there has been an explosion of new developments internationally in the area of war crimes in the last 20 years.

\section{Trials of international crimes}

\section{1. International institutions}

The first international institutions since the post-WWII period were the International Criminal Tribunals for the Former Yugoslavia (ICTY) ${ }^{9}$ and Rwanda (ICTR),${ }^{10}$ which were established in 1994 and 1995 respectively. These tribunals have their own Trial Chambers and a shared Appeals Chamber. The decisions of the Chambers of the two tribunals have greatly contributed to the development of the international law of war crimes, genocide and crimes against humanity. As of December 18, 2014, the ICTY has indicted 161 persons, the cases of 136 of those have been completed, resulting in the conviction and sentencing of 75 persons in 51 separate trial processes, ${ }^{11}$ as well as 20 acquittals, while it also has transferred eight cases involving 13 persons to national jurisdictions, all to Bosnia

6 The Finta case; for the Supreme Court of Canada decision see [1994] 1 S.C.R. 701.

7 There have been three criminal prosecutions in Australia, namely the cases of Berezovsky, Wagner and Polyukhovich; the decision of the High Court of Australia in the last case can be found in 101 Australian Law Reports (1991) p. 545, 172 Commonwealth Law Reports p. 501 and 91 International Law Reports (1993) p. 1.

8 There has been one prosecution in the United Kingdom, namely the Sawoniuk trial which has been the only successful prosecution of a WWII perpetrator based on universal jurisdiction; for an assessment, see 2 Yearbook of International Humanitarian Law (1999), Part III, "National Decisions."

9 The official name is "The International Tribunal for the Prosecution of Persons Responsible for Serious Violations of International Humanitarian Law Committed in the Territory of the Former Yugoslavia since 1991" and was established on May 25, 1993 as the result of Security Council Resolution 837 (UNDOC S/RES/827 (1993).

10 The official name of the tribunal is "The International Criminal Tribunal for the Prosecution of Persons Responsible for Genocide and Other Serious Violations of International Humanitarian Law Committed in the Territory of Rwanda and Rwandan citizens responsible for genocide and other such violations in the territory of neighbouring States, between 1 January 1994 and 31 December 1994" and was established by Security Council Resolution UNDOC S/RES/955 on November 8, 1994.

11 See http://www.un.org/icty/glance-e/index.htm, under "About the ICTY", then "Key Figures of the Cases" 
and Herzegovina except two to Croatia and one to Serbia. ${ }^{12}$ The ICTR has indicted 93 persons of whom 76 have been arrested and 67 convicted in 44 judgments (plus another 12 have been acquitted) while deciding to transfer 11 persons for trial in national jurisdictions, one to the Netherlands, two to France and eight to Rwanda. ${ }^{13}$

Apart from the activities of the two ad hoc tribunals, ${ }^{14}$ there has been a lot of work done under the auspices of the United Nations to establish a permanent international criminal court. The Statute of the International Criminal Court, which was adopted on July $17,1998^{15}$ and amended on June $11,2010,{ }^{16}$ contains definitions of aggression, genocide, crimes against humanity and war crimes, which must be considered at those respective times the most contemporary formulation of international law pertaining to these crimes. The court started operating on July 1, 2002 and has indicted 31 persons in eight situations (nobody has been indicted in the most recent situation, Mali, yet) namely five leaders of the Lord Resistance Army for the Ugandan situation (two of which have died since the approval of the indictment); eight Sudanese persons in respect to the Darfur situation (including the head of state of Sudan); six for the situation in Kenya (the indictments of four have been confirmed but two was withdrawn by the prosecutor); three (including the head of state although the indictment has been withdrawn due to his death) for the situation in Libya; three (including the previous head of state and his wife) for the situation in Ivory Coast, two of whom are in custody; one for the situation involving the Central African Republic who is in custody; and six from the Democratic Republic of the Congo (DRC) regarding war crimes committed in the Ituri and Kivu regions of that country; five of the six indictees for the last situation were in custody at

12 Namely: Jankovic, decided by both the Trial and Appeal Chamber; Stankovic, both TC and AC; Todovic/Rasevic, both TC and AC; Mejakic/Gruban/Knezevic/Dusan Fustar, TC and AC; Ademi/Norac, TC; Ljubicic, TC and AC; Kovacevic, TC and AC, and Trbic, TC, all to BiH except two to Croatia [Ademi/Norac] and one to Serbia [Kovacevic]). The ICTY has also transferred files to other jurisdictions of persons who were investigated but not indicted by the OTP (see http://www.icty.org/sid/103)

13 Bagaragaza, TC and AC to the Netherlands (however, this transfer has been cancelled); Bucyibaruta, TC and Munyeshyaka, TC, to France; the ICTR has also transferred two persons to Rwanda, namely Uwinkindi and Munyagishari, as well as ordering the transfer of the cases of five other persons who are still at large, namely Kayishema, Sikubwabo, Ntaganzwa, Ryandikayo, Ndimbati and Munyarugarama and 55 files (as of August 1, 2014) to Rwanda, which had been investigated but not indicted by the ICTR for further investigation and possible future action by Rwanda (see http://www.unictr.org/tabid/155/Default.aspx?id=1138)

14 Their work has been taken over in part by the United Nations Mechanism for International Criminal Tribunals, see http://www.unmict.org/.

15 The Statute can be found in 37 International Legal Materials p. 999 and on the United Nations website at http://un.org/law/icc. The ICC's own website is http://www.icc-cpi.int/; 122 countries have ratified the Statute.

16 This was the result of the first review conference held in Kampala and contained in Resolution RC/Res. 6. 
the ICC (of which one has been released as ordered by the Pre-Trial Chamber, which was confirmed by the Appeals Chamber). ${ }^{17}$

The first trial (Lubanga) before the ICC was supposed to start on June 23, 2008 but the proceedings were stayed on June 13, 2008 due to irregularities in the prosecution case, a decision which was upheld by the Appeals Chamber on October 21, 2008. However, on November 18, 2008 the stay was lifted and the trial began on January 26, 2009. On July 8, 2010, the Trial Chamber imposed another stay of proceedings, due to the non-implemention of disclosure orders by the court, which was overturned by the Appeals Chamber on October 8, 2010. Lubanga was convicted on March 14, 2012 and sentenced to 14 years imprisonment on July 10, 2012. The conviction and sentence was upheld on December 1, 2014. The second trial (Katanga and Chui) started on November 24, 2009 and the third (Bemba) on November 22, 2010; the Katanga and Chui case was severed with Chui being acquitted on December 18, 2012 and Katanga convicted on March 7, 2014 and sentenced to 12 years on May 23, 2014. He discontinued his appeal on June 25, 2014. ${ }^{18}$

The United Nations has also been instrumental in establishing five hybrid tribunals for dealing with international crimes, ${ }^{19}$ namely the Special Panel for Serious Crimes of the Dili District Court in East Timor (and its Court of Appeal), the Special Court for Sierra Leone, the Extraordinary Chambers of the Courts of Cambodia, the War Crimes Chamber of the state court of Bosnia and Herzegovina and the courts in Kosovo. These courts have (or had) a mixed membership of local and international judges (see Table 1 below for more details with respect to these institutions). There have been discussions to set up other internationalized tribunals, such as in Liberia, Burundi ${ }^{20}, \mathrm{Kenya}^{21}$ and the Democratic Republic of the Congo ${ }^{22}$ but these have not resulted in the establishment of any such institutions.

17 See http://www.icc-cpi.int/en_menus/icc/situations\%20and\%20cases/Pages/situations\%20 and\%20cases.aspx as well as Ambos, Treatise on International Criminal Law, Volume I: Foundations and General Part (OUP 2013) pp. 35-40.

18 For more details of the work of the court, see http://www.icc-cpi.int/iccdocs/asp_docs/ASP11/ ICC-ASP-11-21-ENG.pdf.

19 The United Nations has also established a sixth tribunal based on an agreement with a national state with international aspects, namely the Special Tribunal for Lebanon, but this tribunal does not have the same jurisdiction as the other tribunals (See article 1 of the Agreement which is attached as an Annex to Security Council Resolution 1757 (2007), May 30, 2007); the Trial Chamber confirmed the indictment involving four persons on June 28, 2011 while on February 1,2012 it allowed the trial of the four accused to proceed in absentia; on October 10, 2013 a fifth person was charged while the trial started on January 16, 2014.

20 http://www.rnw.nl/international-justice/article/negotiations-reconciliation-commissionspecial-tribunal-resume-burundi.

21 http://news.bbc.co.uk/2/hi/8177525.stm.

22 http://www.rnw.nl/international-justice/article/international-tribunal-congo-\%E2\%80\%93-aroad-map. 
Table 1: Internationalized Tribunals with Jurisdiction for International Crimes ${ }^{23}$

\begin{tabular}{|c|c|c|c|c|c|c|}
\hline & East Timor & Kosovo & Sierra Leone & Cambodia & $\begin{array}{l}\text { Bosnia and } \\
\text { Herzegovina }\end{array}$ & Iraq \\
\hline Official Name & $\begin{array}{l}\text { Panels with } \\
\text { Exclusive } \\
\text { Jurisdiction over } \\
\text { Serious Offences }\end{array}$ & $\begin{array}{l}\text { None, regular } \\
\text { courts }\end{array}$ & $\begin{array}{l}\text { Special Court for } \\
\text { Sierra Leone }\end{array}$ & $\begin{array}{l}\text { Extraordinary } \\
\text { Chambers of } \\
\text { the Courts of } \\
\text { Cambodia }\end{array}$ & $\begin{array}{l}\text { War Crimes } \\
\text { Chamber of } \\
\text { the State Court } \\
\text { of Bosnia and } \\
\text { Herzegovina }\end{array}$ & $\begin{array}{l}\text { Iraqi Special } \\
\text { Tribunal, later } \\
\text { called the Iraqi } \\
\text { High Tribunal }\end{array}$ \\
\hline Type of Tribunal & $\begin{array}{l}\text { Established } \\
\text { by the United } \\
\text { Nations } \\
\text { Transitional } \\
\text { Administration } \\
\text { for East Timor } \\
\text { (UNTAET) }\end{array}$ & $\begin{array}{l}\text { Established } \\
\text { by the United } \\
\text { Nations Interim } \\
\text { Administration } \\
\text { Mission } \\
\text { in Kosovo } \\
\text { (UNMIK) } \\
\text { followed in } 2008 \\
\text { by the European } \\
\text { Union Rule of } \\
\text { Law Mission } \\
\text { (EULEX) }\end{array}$ & $\begin{array}{l}\text { Agreement } \\
\text { between United } \\
\text { Nations and the } \\
\text { Government of } \\
\text { Sierra Leone }\end{array}$ & $\begin{array}{l}\text { Agreement } \\
\text { between United } \\
\text { Nations and the } \\
\text { Government of } \\
\text { Cambodia }\end{array}$ & $\begin{array}{l}\text { Joint initiative } \\
\text { of the ICTY } \\
\text { and the Office } \\
\text { of the High } \\
\text { Representative } \\
\text { in Bosnia and } \\
\text { Herzegovina } \\
\text { (OHR) }\end{array}$ & $\begin{array}{l}\text { The first iteration } \\
\text { established by the } \\
\text { Iraqi Coalition } \\
\text { Provisional } \\
\text { Authority, the } \\
\text { second by the } \\
\text { Iraqi Transitional } \\
\text { National } \\
\text { Assembly }\end{array}$ \\
\hline $\begin{array}{l}\text { Dates of } \\
\text { Operation }\end{array}$ & $\begin{array}{l}\text { June 6, 2000-May } \\
1,2005\end{array}$ & $\begin{array}{l}\text { As of June 10, } \\
1999\end{array}$ & $\begin{array}{l}\text { January 16, } 2002 \\
\text { - December 3, } \\
2013\end{array}$ & $\begin{array}{l}\text { As of May 7, } \\
2006\end{array}$ & $\begin{array}{l}\text { As of March 9, } \\
2005\end{array}$ & $\begin{array}{l}\text { As of December } \\
10,2003\end{array}$ \\
\hline $\begin{array}{l}\text { Temporal } \\
\text { Jurisdiction }\end{array}$ & $\begin{array}{l}\text { Offences } \\
\text { committed } \\
\text { between January } \\
1 \text { to October 25, } \\
1999\end{array}$ & None & $\begin{array}{l}\text { Offences } \\
\text { committed since } \\
\text { November 30, } \\
1996\end{array}$ & $\begin{array}{l}\text { Offences } \\
\text { committed } \\
\text { between April 17, } \\
1975 \text { and January } \\
6,1979\end{array}$ & $\begin{array}{l}\text { Offences } \\
\text { committed } \\
\text { between } 1992 \\
\text { and } 1995\end{array}$ & $\begin{array}{l}\text { Offences } \\
\text { committed } \\
\text { between July 17, } \\
1968 \text { and May 1, } \\
2003\end{array}$ \\
\hline $\begin{array}{l}\text { International } \\
\text { Aspects }\end{array}$ & $\begin{array}{l}\text { Majority of } \\
\text { International } \\
\text { Judges }\end{array}$ & $\begin{array}{l}\text { Majority of } \\
\text { International } \\
\text { Judges (at } \\
\text { request) }\end{array}$ & $\begin{array}{l}\text { Majority of } \\
\text { International } \\
\text { Judges }\end{array}$ & $\begin{array}{l}\text { Minority of } \\
\text { International } \\
\text { Judges }\end{array}$ & $\begin{array}{l}\text { Majority of } \\
\text { International } \\
\text { Judges (to be } \\
\text { phased out by } \\
2012 \text { ) }\end{array}$ & $\begin{array}{l}\text { No International } \\
\text { Judges but } \\
\text { International } \\
\text { Monitoring }\end{array}$ \\
\hline $\begin{array}{l}\text { Subject } \\
\text { Jurisdiction } \\
\text { (International } \\
\text { Crimes) }\end{array}$ & $\begin{array}{l}\text {-Genocide } \\
\text {-International } \\
\text { War Crimes } \\
\text {-Crimes against } \\
\text { Humanity }\end{array}$ & $\begin{array}{l}\text {-Genocide } \\
\text {-War Crimes }\end{array}$ & $\begin{array}{l}\text {-Non- } \\
\text { International } \\
\text { War Crimes } \\
\text {-Crimes against } \\
\text { Humanity }\end{array}$ & $\begin{array}{l}\text {-Genocide } \\
\text {-International } \\
\text { War Crimes } \\
\text {-Crimes against } \\
\text { Humanity }\end{array}$ & $\begin{array}{l}\text {-Genocide } \\
\text {-War Crimes } \\
\text {-Crimes against } \\
\text { Humanity }\end{array}$ & $\begin{array}{l}\text {-Genocide } \\
\text {-War Crimes } \\
\text {-Crimes against } \\
\text { Humanity }\end{array}$ \\
\hline $\begin{array}{l}\text { Inspiration for } \\
\text { International } \\
\text { Crimes }\end{array}$ & ICC Statute & Not Applicable & $\begin{array}{l}\text { ICTY/ICTR/ } \\
\text { ICC Statutes }\end{array}$ & $\begin{array}{l}\text { ICTY/ICTR } \\
\text { Statutes }\end{array}$ & ICTY Statute & ICC Statute \\
\hline $\begin{array}{l}\text { Subject } \\
\text { Jurisdiction } \\
\text { (Domestic } \\
\text { Crimes) }\end{array}$ & $\begin{array}{l}\text {-Murder } \\
\text {-Sexual Offences } \\
\text {-Torture }\end{array}$ & All crimes & $\begin{array}{l}\text {-Abuse of Girls } \\
\text {-Wanton } \\
\text { Destruction of } \\
\text { Property }\end{array}$ & $\begin{array}{l}\text {-Murder } \\
\text {-Torture } \\
\text {-Religious } \\
\text { Persecution }\end{array}$ & -Organized crime & $\begin{array}{l}\text {-Manipulation of } \\
\text { Judiciary } \\
\text {-Wastage } \\
\text { of Natural } \\
\text { Resources } \\
\text {-Aggression } \\
\end{array}$ \\
\hline Defender's office & No & No & Yes & Yes & Yes & Yes \\
\hline Number of cases & 84 & 83 & 10 & 2 & 100 & 17 \\
\hline
\end{tabular}

23 For more information regarding these tribunals, see Currie \& Rikhof, International and Transnational Criminal Law (Irwin Law 2013) pp. 212-224; Ambos 2013 op. cit., pp. 40-54. 
Joseph Rikhof

\subsection{Domestic trials of international crimes ${ }^{24}$}

There have been processes involving international crimes based on territorial or active nationality jurisdiction in 32 countries (including the three internationalized domestic courts in Bosnia and Herzegovina, Kosovo and East Timor), namely seven in Europe, eleven in Latin America, four in Asia and ten in Africa resulting in over 16,000 convictions since 1995.

In Europe, apart from the national courts in Bosnia and Herzegovina and Kosovo, both of which were discussed above because of their international aspects, there have been a number of other war crimes prosecutions in the former Yugoslavia, namely in Serbia, Croatia, Montenegro and Slovenia, as well as in Romania, Hungary and Lithuania, although in the latter three countries charges were laid for crimes committed in the fifties and sixties and only one of the four trials has resulted in a conviction so far, namely in Hungary.

In Central and South America, ten countries have started criminal investigations and prosecutions against persons involved in war crimes, crimes against humanity and genocide carried out under previous regimes, namely in Chile, Peru, Colombia, Argentina, Uruguay, Bolivia, Brazil, Guatemala, Haiti and Mexico while Paraguay has used the extradition approach for similar crimes. ${ }^{25}$

In Asia, Indonesia, Afghanistan and Bangladesh have initiated international crime trials, the latter pertaining to the time that Bangladesh become independent, namely 1971, while Israel has effected the extradition of a suspected war criminal to Bosnia.

In Africa, prosecutions have begun in eight countries, namely the Republic of the Congo, the Democratic Republic of the Congo, Ethiopia, Rwanda, Burundi, Uganda, Guinea and Ivory Coast while South Africa has started an investigation into internation-

24 For more details of the trials referred below, see the website of TRIAL Watch at http://www.trialch.org/en/resources/trial-watch/trial-watch.html.

25 See http://www.icso.cl/wp-content/uploads/2013/07/Cifras_septiembre_2012_ENG.pdf; for a detailed discussion of the jurisprudence in this area, see Digest of Latin American Jurisprudence on International Crimes, Volumes I and II at http://www.dplf.org/sites/default/files/digesto_ jurisprudencia_en_pdf_0.pdf; for a general overview, see Ambos 2013, op. cit., pp. 114-117 as well as Volume 10, Number 4 of the 2010 edition of the International Criminal Law Review; see also 'Nunca Más': Connecting Latin American Approaches to Impunity with Positive Complementarity Using Technology Driven Resources, By Emilie Hunter, Dorothy EstradaTanck and María Luisa Piqué, FICHL Policy Brief Series No. 16 (2013) at http://www.fichl.org/ fileadmin/fichl/documents/FICHL_Policy_Brief_Series/FICHL_PB16_EN.pdf. 
al crimes and Kenya has established an International Crimes Division within its High Court, which has not begun operating yet.

Table 2 below provides more detail of completed trials and convictions in these countries (as a result of which the ongoing trials in Brazil, Haiti, Guinea, Uganda and Ivory Coast are not included while the acquittal of the persons charged in Mexico and the Republic of the Congo are not part of the table nor is the one conviction in Hungary).

\section{Table 2: Territorial Jurisdiction Trials}

\begin{tabular}{|c|c|c|c|c|c|}
\hline Country of Trials & $\begin{array}{l}\text { Country where } \\
\text { crimes occurred }\end{array}$ & Crime(s) & $\begin{array}{l}\text { Number of } \\
\text { convictions }^{26}\end{array}$ & $\begin{array}{l}\text { Range of } \\
\text { conviction dates }\end{array}$ & $\begin{array}{l}\text { Range of } \\
\text { sentences }{ }^{27}\end{array}$ \\
\hline Serbia & Serbia & $\begin{array}{l}\text { War Crimes / } \\
\text { Crimes against } \\
\text { Humanity }\end{array}$ & 56 & $2005-2012$ & $5-81$ years \\
\hline Croatia & Croatia & $\begin{array}{l}\text { War Crimes / } \\
\text { Crimes against } \\
\text { Humanity }\end{array}$ & $233^{28}$ & $1991-2012$ & $\begin{array}{l}6 \text { months }-20 \\
\text { years }\end{array}$ \\
\hline Montenegro & Croatia & Torture & 6 & 2010 & $\begin{array}{l}18 \text { months }-4 \\
\text { years }\end{array}$ \\
\hline Slovenia & Slovenia & War Crimes & 1 & 2013 & five years \\
\hline Chile & Chile & $\begin{array}{l}\text { Crimes against } \\
\text { Humanity / } \\
\text { Torture }\end{array}$ & 30 & $2006-2012$ & 4 years - life \\
\hline Peru & Peru & $\begin{array}{l}\text { Crimes against } \\
\text { Humanity }\end{array}$ & 3 & $2007-2009$ & 16 years - life \\
\hline Colombia & Colombia & $\begin{array}{l}\text { Crimes against } \\
\text { Humanity }\end{array}$ & 9 & $2010-2012$ & $8-40$ years \\
\hline Argentina & Argentina & $\begin{array}{l}\text { Crimes against } \\
\text { Humanity / } \\
\text { Torture }\end{array}$ & $400+$ & $2006-2013$ & 8 years - life \\
\hline Uruguay & Uruguay & $\begin{array}{l}\text { Crimes against } \\
\text { Humanity }\end{array}$ & 1 & 2009 & 25 years \\
\hline Bolivia & Bolivia & Genocide & 7 & 2011 & $3-15$ years \\
\hline
\end{tabular}

26 All conviction figures are approximate.

$27 \quad$ All sentencing figures are approximate.

28 Between 1991 and 2006, there were an additional 611 convictions for war crimes and crimes against humanity in Croatian courts. However, the lawfulness of a significant number of these convictions has been called into question, and many of these trials were conducted in absentia. 


\begin{tabular}{|c|c|c|c|c|c|}
\hline Country of Trials & $\begin{array}{l}\text { Country where } \\
\text { crimes occurred }\end{array}$ & Crime(s) & $\begin{array}{l}\text { Number of } \\
\text { convictions }^{26}\end{array}$ & $\begin{array}{l}\text { Range of } \\
\text { conviction dates }\end{array}$ & $\begin{array}{l}\text { Range of } \\
\text { sentences }^{27}\end{array}$ \\
\hline Guatemala & Guatemala & $\begin{array}{l}\text { Crimes against } \\
\text { Humanity / War } \\
\text { Crimes / Torture }\end{array}$ & 11 & $2009-2012$ & $53-7710$ years \\
\hline Indonesia & Indonesia & $\begin{array}{l}\text { Crimes against } \\
\text { Humanity }\end{array}$ & 6 & 2002 & $3-10$ years \\
\hline Afghanistan & Afghanistan & War Crimes & 1 & 2006 & death \\
\hline Bangladesh & Bangladesh & $\begin{array}{l}\text { War Crimes / } \\
\text { Genocide }\end{array}$ & 13 & 2013-2014 & 90 years - death \\
\hline DRC & DRC & $\begin{array}{l}\text { Crimes against } \\
\text { Humanity / War } \\
\text { Crimes }\end{array}$ & 20 & $2006-2010$ & 5 years - death \\
\hline Ethiopia & Ethiopia & Genocide & $5,000+$ & $1996-2008$ & 10 years - death \\
\hline Rwanda ${ }^{29}$ & Rwanda & $\begin{array}{l}\text { Genocide / War } \\
\text { Crimes / Crimes } \\
\text { against Humanity }\end{array}$ & $10,000+$ & $1996-2006$ & 5 years - death \\
\hline Burundi & Burundi & $\begin{array}{l}\text { Crimes against } \\
\text { Humanity }\end{array}$ & 4 & 2008 & life - death \\
\hline
\end{tabular}

29 In addition to the regular court system, Rwanda also established a community based court system called gacaca from 2005-2012; around 1.2 million people were processed through this system; in 2012, the Rwandan government established a specialized chamber in the High Court to hear cases involving international crimes. 


\subsection{Universal jurisdiction trials}

In Europe $\mathrm{e}^{30} 12$ countries have initiated criminal prosecutions for international crimes $^{31}$ committed elsewhere between 1994 and 2014, resulting in 43 indictments (of which almost $90 \%$ since 2000 alone) with 40 persons convicted (in 32 cases) and three acquittals. A number of countries (Austria, Denmark, France, Germany, Italy, the Netherlands, Norway, Spain, Sweden, Switzerland and the United Kingdom) have also extradited persons suspected for such crimes or are in the process of doing so, mostly to Rwanda or countries of the former Yugoslavia although in some cases also to international institutions.

In North America two countries, the United States ${ }^{32}$ and Canada, have completed four criminal trials for international crimes, three in Canada (with one acquittal) and one in the United States; both countries have also extradited persons for involvement in genocide, crimes against humanity and war crimes.

Australia has been working on two extradition cases in respect of Croatia.

In Africa, South Africa has started two investigations against nationals of other African states, namely Madagascar and Zimbabwe while in Senegal a hybrid regional court was established to investigate and prosecute crimes against humanity committed in Chad. $^{33}$

30 In addition to these investigative and prosecutorial efforts by individual countries, there have also been attempts at co-ordinating these activities by improving exchange of information pertaining to investigations and by establishing best practices. Interpol has convened four International Expert Meetings on Genocide, War Crimes, and Crimes Against Humanity since 2005; see in general http://www.interpol.int/Crime-areas/Fugitive-investigations/War-crimes and http://www.interpol.int/News-and-media/News-media-releases/2009/PR049, while three years earlier the European Union decided to establish an European network of contact points in respect of persons responsible for genocide, crimes against humanity and war crimes, which meets on a regular basis, see the Official Journal of the European Communities L167/1 of $26 / 6 / 2002$ and L118/2 of 14/5/2003. As well, the ICC has started to convene meetings with some of the specialized war crimes units in order to develop an efficient co-operation model between national states and the ICC based on the complementarity principle enshrined in article 17 of its Statute. On the non-governmental side, the International Association of Prosecutors (IAP) established in 2009 a Specialist War Crimes Forum (http://www.iap-association.org/FICJ/ Home.aspx) while the International Bar Association had formed a War Crimes Committee a year earlier (http://www.ibanet.org/PPID/Constituent/War_Crimes_Committee/Default.aspx).

31 In most cases the international crimes considered in this section are war crimes and genocide although in some instances crimes against humanity were charged as well as torture, as defined by the 1984 Torture Convention.

32 The U.S. has also arrested a number of persons for involvement in atrocities in their homeland but these prosecutions are launched under its immigration legislation for immigration fraud, resulting in both criminal convictions as well as deportations to the country where the crimes were committed.

33 For more information re the court in Senegal, see Currie \& Rikhof 2013, op. cit. at note 23, pp. 224-225. 
For details of the completed criminal trials in the 14 countries mentioned above, see table 3.

\section{Table 3: Universal Jurisdiction Trials}

\begin{tabular}{|c|c|c|c|c|c|}
\hline Country of trial & $\begin{array}{l}\text { Country where } \\
\text { crimes occurred }\end{array}$ & $\begin{array}{l}\text { Conviction and } \\
\text { date }\end{array}$ & $\begin{array}{l}\text { Crimes } \\
\text { mentioned in } \\
\text { judgment }\end{array}$ & Sentence & Appeal \\
\hline Netherlands & DRC & Yes; 2004 & torture & 10 years & No \\
\hline Netherlands & $\begin{array}{l}\text { Afghanistan (two } \\
\text { persons) }\end{array}$ & Yes; 2005 & $\begin{array}{l}\text { war crimes/ } \\
\text { torture }\end{array}$ & 9 and 12 years & Yes; decision upheld \\
\hline Netherlands ${ }^{34}$ & $\begin{array}{l}\text { Netherlands/ } \\
\text { Iraq }\end{array}$ & Yes; 2005 & war crimes & 15 years & $\begin{array}{l}\text { Yes; decision upheld; } \\
\text { again upheld by the } \\
\text { ECtHR }\end{array}$ \\
\hline Netherlands ${ }^{34}$ & $\begin{array}{l}\text { Netherlands/ } \\
\text { Liberia }\end{array}$ & Yes; 2006 & $\begin{array}{l}\text { UN sanctions } \\
\text { violation }\end{array}$ & 8 years & $\begin{array}{l}\text { Yes; decision } \\
\text { overruled by appeals } \\
\text { court but reinstated } \\
\text { by Supreme Court }\end{array}$ \\
\hline Netherlands & Afghanistan & No; 2007 & $\begin{array}{l}\text { war crimes / } \\
\text { torture }\end{array}$ & $\mathrm{N} / \mathrm{A}$ & No \\
\hline Netherlands & Rwanda & No; 2007 & genocide & N/A & Yes; acquittal upheld \\
\hline Netherlands ${ }^{35}$ & Rwanda & Yes, 2009 & torture & 20 years & $\begin{array}{l}\text { Yes, sentence } \\
\text { increased to life } \\
\text { imprisonment }\end{array}$ \\
\hline Netherlands ${ }^{36}$ & $\begin{array}{l}\text { Sri Lanka (five } \\
\text { persons) }\end{array}$ & Yes, 2011 & $\begin{array}{l}\text { terrorism and war } \\
\text { crimes }\end{array}$ & $2-6$ years & $\begin{array}{l}\text { Yes, both sentence } \\
\text { and fact that war } \\
\text { crimes aspect was } \\
\text { denied }\end{array}$ \\
\hline Netherlands & Rwanda & Yes, 2013 & genocide & $\begin{array}{l}6 \text { years, } 8 \\
\text { months }\end{array}$ & No \\
\hline Belgium & $\begin{array}{l}\text { Rwanda (four } \\
\text { persons) }\end{array}$ & Yes; 2001 & war crimes & $12-20$ years & No \\
\hline Belgium & $\begin{array}{l}\text { Rwanda (two } \\
\text { persons) }\end{array}$ & Yes; 2005 & murder & 10 and 12 years & No \\
\hline Belgium & Rwanda & Yes, 2009 & war crimes & 30 years & Yes, decision upheld \\
\hline
\end{tabular}

34 As the accused was a Dutch national, it is not strictly correct to include this case as part of universal jurisdiction but it is relevant as the crimes occurred outside Netherlands.

35 This is the same case as the one mentioned before but with different charges.

36 As some of the offences occurred in the Netherlands it is not strictly correct to include this case as part of universal jurisdiction but it is relevant as war crimes, some of which were alleged to have occurred outside the Netherlands, were included in the indictment. 


\begin{tabular}{|c|c|c|c|c|c|}
\hline Country of trial & $\begin{array}{l}\text { Country where } \\
\text { crimes occurred }\end{array}$ & $\begin{array}{l}\text { Conviction and } \\
\text { date }\end{array}$ & $\begin{array}{l}\text { Crimes } \\
\text { mentioned in } \\
\text { judgment }\end{array}$ & Sentence & Appeal \\
\hline Belgium & Rwanda & Yes, 2007 & murder & 20 years & Yes; decision upheld \\
\hline Germany & Bosnia & Yes, 1997 & manslaughter & 5 years & No \\
\hline Germany & Bosnia & Yes, 1997 & genocide/ murder & life & $\begin{array}{l}\text { Yes; decision upheld; } \\
\text { again upheld by the } \\
\text { ECtHR }\end{array}$ \\
\hline Germany & Bosnia & Yes, 1999 & $\begin{array}{l}\text { genocide/war } \\
\text { crimes }\end{array}$ & 9 years & Yes; decision upheld \\
\hline Germany & Bosnia & Yes, 1999 & $\begin{array}{l}\text { genocide/war } \\
\text { crimes }\end{array}$ & life & $\begin{array}{l}\text { Yes; decision upheld } \\
\text { but only for war } \\
\text { crimes }\end{array}$ \\
\hline Germany & Rwanda & Yes, 2014 & genocide & 14 years & Under appeal \\
\hline France & Argentina & $\begin{array}{l}\text { Yes (in absentia), } \\
1990\end{array}$ & torture & life & No \\
\hline France & Mauritania & $\begin{array}{l}\text { Yes (in absentia), } \\
2006\end{array}$ & torture & 10 years & $\begin{array}{l}\text { Yes; complaint } \\
\text { to ECtHR held } \\
\text { inadmissible }\end{array}$ \\
\hline France & Tunisia & $\begin{array}{l}\text { Yes (in absentia), } \\
2008\end{array}$ & torture & 8 years & $\begin{array}{l}\text { Yes, decision upheld } \\
\text { and sentence } \\
\text { increased to } 12 \text { years }\end{array}$ \\
\hline France & Rwanda & Yes, 2014 & $\begin{array}{l}\text { genocide/crimes } \\
\text { against humanity }\end{array}$ & 25 years & Not yet \\
\hline Sweden & Bosnia & Yes, 2011 & war crimes & 5 years & No \\
\hline Sweden & Kosovo & Yes, 2012 & $\begin{array}{l}\text { crimes against } \\
\text { humanity }\end{array}$ & life & $\begin{array}{l}\text { Yes, decision } \\
\text { overturned }\end{array}$ \\
\hline Sweden & Rwanda & Yes, 2013 & genocide & life & Yes, decision upheld \\
\hline Canada $^{37}$ & Bosnia & Yes, 2005 & hostage taking & 3 years & Yes, decision upheld \\
\hline Canada & Rwanda & Yes, 2009 & $\begin{array}{l}\text { genocide, crimes } \\
\text { against humanity, } \\
\text { war crimes }\end{array}$ & life & $\begin{array}{l}\text { Yes, decision upheld } \\
\text { and confirmed by the } \\
\text { Supreme Court }\end{array}$ \\
\hline Canada & Rwanda & No, 2013 & $\begin{array}{l}\text { genocide, crimes } \\
\text { against humanity }\end{array}$ & N/A & No \\
\hline Norway & Bosnia & Yes, 2008 & $\begin{array}{l}\text { torture/ } \\
\text { rape/forcible } \\
\text { confinement } \\
\text { (charges for } \\
\text { international } \\
\text { crimes held to be } \\
\text { unconstitutional) }\end{array}$ & 5 years & $\begin{array}{l}\text { Yes; all aspects of the } \\
\text { decision upheld by } \\
\text { appeals court and } \\
\text { Supreme Court }\end{array}$ \\
\hline
\end{tabular}

37 As the accused was a Canadian national, it is not strictly correct to include this case as part of universal jurisdiction but it is relevant as the crimes occurred outside Canada. 
Joseph Rikhof

\begin{tabular}{|l|l|l|l|l|l|}
\hline Country of trial & $\begin{array}{l}\text { Country where } \\
\text { crimes occurred }\end{array}$ & $\begin{array}{l}\text { Conviction and } \\
\text { date }\end{array}$ & $\begin{array}{l}\text { Crimes } \\
\text { mentioned in } \\
\text { judgment }\end{array}$ & Sentence & Appeal \\
\hline Norway & Rwanda & Yes, 2013 & genocide & 21 years & Under appeal \\
\hline Spain & Argentina & Yes, 2005 & genocide & 640 years & Yes; decision upheld \\
\hline Switzerland & Rwanda & Yes, 1999 & war crimes & life & $\begin{array}{l}\text { Yes, decision upheld } \\
\text { but sentence reduced } \\
\text { to 14 years which } \\
\text { upheld again on } \\
\text { further appeal }\end{array}$ \\
\hline Switzerland & Guatemala & Yes, 2014 & $\begin{array}{l}\text { Extrajudicial } \\
\text { killing }\end{array}$ & life & Yes \\
\hline Denmark & Bosnia & Yes, 1994 & war crimes & 8 years & Yes; decision upheld \\
\hline UK & Afghanistan & Yes, 2005 & $\begin{array}{l}\text { torture/hostage } \\
\text { taking }\end{array}$ & 20 years & No \\
\hline Austria & Bosnia & No, 1994 & genocide/murder & N/A & No \\
\hline Finland & Rwanda & Yes, 2010 & genocide & life & Yes; decision upheld \\
\hline U.S. & Liberia & Yes, 2009 & torture & 97 years & Yes, decision upheld \\
\hline
\end{tabular}

\subsection{Observations regarding international and domestic prosecutions}

A number of comments can be made about the efforts in the last two decades to put perpetrators of international crimes on trial.

The first important observation, which applies to both international and domestic practice, is the fact that 19 erstwhile $^{38}$ and two sitting ${ }^{39}$ heads of state have been indicted, prosecuted or sentenced for international crimes. ${ }^{40}$ Of the five trials begun at the inter-

38 The case of Radovan Karadzic, who was the war-time president of the Republika Srpska in Bosnia and Herzegovina in the early nineties and who was indicted by the ICTY in 1995 and arrested on July 21,2008, is not included in this number nor is the case of Jean-Claude "Baby Doc" Duvalier who was investigated for but not charged with crimes against humanity.

39 The ICC Pre-Trial Chamber issued a warrant for arrest for Al Bashir, the president of Sudan on March 4, 2009 for war crimes and crimes against humanity, which was extended to genocide on July 12, 2010 while an arrest warrant for crimes against humanity was issued for Gaddafi on June 27, 2011 in respect to the Libyan situation; the warrant for arrest for Gbagbo was issued on November October 23, 2011.

40 While four others have been tried (Pol Pot in Cambodia), indicted (Bordaberry in Uruguay) or convicted (Ben Ali in Tunisia and Mubarak in Egypt) for regular (but similar in seriousness as opposed to a large number of corruption or property charges leveled in other cases) crimes by domestic courts; for more background see Olasolo, Criminal Responsibility of Political and Military Leaders for Genocide, Crimes against Humanity and War Crimes: with Special Reference to the Rome Statute and the Statute and Case Law of the Ad Hoc Tribunals (Hart Publishing 2008); Olasolo, The Criminal Responsibility of Senior Political and Military Leaders as Principals to International Crimes (Hart Publishing, 2009); and Lutz \& Reiger (eds.), Prosecuting Heads of State, (CUP 2009), especially the Appendix at pages 295-304. 
national level (of the cases of the two heads of state indicted by the ICC, Omar Al Bashir from Sudan and Muammar Gadaffi of Libya, the former is in the pre-trial phase and at large while the latter has died while another ex-head of State, Laurent Gbagbo of Ivory Coast, has also been indicted) the ICTR sentenced the prime minister of Rwanda during the 1994 genocide, Jean Kambanda, to life imprisonment in $1998 .^{41}$ President Slobodan Milosevic of the former Yugoslavia was indicted by the ICTY in 1999 and 2001 and put on trial in 2002, which would have been completed if he had not died while in custody during the proceedings in 2006. The Sierra Leone Special Court indicted the former president of Liberia, Charles Taylor, in 2006 and his trial started in early 2008 ending with a conviction in 2012 in The Hague. Another hybrid tribunal, the Special Court of Iraq, completed proceedings against Saddam Hussein in 2006 resulting in his execution the same year. Khieu Samphan, the former president of Democratic Kampuchea, was investigated by the Extraordinary Chambers in the Courts of Cambodia (ECCC), his trial started in June 2011, and he was convicted and sentenced to life imprisonment on August 7, 2014. In addition, there have 13 attempts at the domestic level to take action against former heads of state since $1992 .^{42}$

Secondly, an encouraging trend is the fact that there have been some proceedings against corporate players, albeit some have not been successful in the end. While the prosecution of corporate executives is not a new phenomenon as there had already been prosecutions of this kind after the Second World War against German corporate officials, including by the International Military Tribunal in Nuremberg, ${ }^{43}$ the international and hybrid tribunals have not ventured into this area so far. On the domestic front there have been two convictions in the Netherlands for corporate executives for providing weapons to the Charles Taylor regime in Liberia and for selling precursors for chemical weapons to the Saddam Hussein regime in Iraq.

41 ICTR 97-23-S, September 4, 1998, upheld by the Appeals Chamber on October 19, 2000, ICTR 97-23-A.

42 While international institutions can bring sitting heads of state to justice, national states can only do so against former heads of state according to the International Court of Justice in the Democratic Republic of the Congo versus Belgium case, decided February 14, 2003. For more information, see Currie \& Rikhof 2013, op.cit., p. 3, footnote 9.

43 Gustav Krupp von Bohlen und Halbach was indicted but did not stand trial during the IMT proceedings due to mental illness. Other trials carried out against industrialists included the Krupp (Law Reports of Trials of War Criminals, Volume X, 69), Flick (Law Reports of Trials of War Criminals, Volume IX, 1), I.G. Farben (Law Reports of Trials of War Criminals, Volume X, 1), Zyklon B (Law Reports of Trials of War Criminals, Volume I, 93) and the Roechling (Law Reports of Trials of War Criminals, Volume X, 56-57) trials. 
In the DRC, during the Kilwa trial both Congolese soldiers and three executives of the mining company Anvil were charged for war crimes but eventually acquitted in 2007;4 this same incident is being investigated in Australia. In addition, two executives of the French oil company TotalFinaElf have been indicted in both France and Belgium in 2002 for involvement in crimes against humanity in Burma; the proceedings in Belgium came to an end in 2008. Although it might be difficult for international institutions to hold corporations themselves responsible for breaches of international criminal law (it is for instance explicitly forbidden in the Rome Statute), ${ }^{45}$ it is clear that the human actors representing such corporations are not immune from the reaches of this area of the law.

Thirdly, there are differences between the number of trials held and their modalities. Four categories can be distinguished, namely the truly international institutions (ICC, ICTY and ICTR) together with the two tribunals established by an agreement between the United Nations and a domestic jurisdiction (the SLSC and ECCC); national tribunals with some international aspects (Bosnia, Kosovo, East Timor and Iraq); domestic courts exercising territorial jurisdiction; and domestic courts exercising universal jurisdiction. In terms of number of cases processed, the first and last categories have generally only be able to deal with a small numbers of situations while the second and third groups typically were able to put on trial much larger numbers of suspects.

This is not entirely surprising given the fact that the ICC, ICTY, ICTR and universal jurisdiction courts had to carry out their investigations outside their jurisdiction or where their seat was established. This is combined with the fact that these institutions, as well as the SLSC and ECCC, because of finite resources and their limited mandate of investigating the persons most responsible, can only measure their success in some dozens of cases -with somewhat higher numbers for institutions which have been operating for a much longer time and with more resources, such as the ICTY and ICTR. On other hand, national courts operating on the basis of territorial jurisdiction (either purely domestic courts or such courts with some international dimensions) were able to bring to justice hundreds and sometimes thousands of perpetrators. Of the 46 countries that have become involved in the prosecutions of perpetrators of international crimes in the last twenty years, the vast majority of convictions occurred in the national courts with territorial jurisdiction. More than 16,000 perpetrators have been brought to justice in 32 such countries compared to 180 persons convicted by the five international(ized) institutions (138) and the 14 countries relying on universal jurisdiction (42) combined.

44 The trial has been severely and widely criticized. Two of the more poignant commentaries are that of the United Nations High Commissioner of Human Rights of July 4, 2007 and the detailed report by the NGO Global Witness of July 17, 2007 (http://www.globalwitness.org/library/ victims-kilwa-massacre-denied-justice-congolese-military-court).

45 Article 25.1. In the United States this type of liability was denied under the Alien Tort Statute, see Kiobel v. Royal Dutch Petroleum, US Court of Appeal, $2^{\text {nd }}$ Circuit, September 17, 2010 with lengthy discussion of international law on this point. 
The last observation is related to the above in that the level of responsibility of persons convicted in criminal trials varies. The five international institutions, as a result of their objective to only investigate those most responsible, have put on trial persons who had exercised powerful or high level functions within their governments or organizations while on the other side of the spectrum, the universal jurisdictions courts typically prosecuted lower level operators with direct personal involvement. ${ }^{46}$ Domestic courts exercising territorial jurisdiction ran the gamut of type of perpetrators, from high officials based on extended liability principles, through direct perpetrators, to persons on the ground committing crimes in an indirect fashion. It is likely that the prosecutors in universal jurisdiction countries had many more suspects given the fact that most criminal suspects had gone through refugee determination or immigration processes first ${ }^{47}$ (while senior perpetrators often stayed away from these countries), which are often decided on indirect participation, but that because of resources limitations only the most serious of these cases were selected for criminal investigations.

The combination of taking action against both the leadership up to and including heads of state or leaders of non-governmental militia (as was done by the ICC in the cases of the LRA leadership in the Ugandan case and four indictments for the situation in the $\mathrm{DRC}$ ), and down to the purveyors of the means to carry out international crimes, sends out the powerful message that the international community understands the complex forces involved in carrying out these crimes and it is willing to take action against both direct and indirect participants.

\section{Participation in international crimes}

\subsection{Introduction}

Both international and domestic institutions have developed theories of liability in order to extend the circle of perpetrators beyond those who have been personally involved. Since the foundation of international criminal law there have been a number of concepts to hold persons liable for the commission of international crimes ${ }^{48}$ in addition to person-

46 See for instance, Human Rights Watch, The Long Arm of Justice Lessons from Specialized War Crimes Units in France, Germany, and the Netherlands (2014) at 13.

47 See Rikhof, The Criminal Refugee, The Treatment of Asylum Seekers with a Criminal Background in International and Domestic Law (Republic of Letters 2013) pp. 460-469.

48 For a general overview of the principles in article 25.3 of the ICC Statute, including the notion of hierarchy of blameworthiness, see Judgment, Katanga (ICC- ICC-01/04-01/07), Trial Chamber, March 7, 2014, \$\$ 1383-1387. 
ally committing such crimes. ${ }^{49}$ Table 4 sets out the various forms of extended liability for completed offences.

Table 4: Modes of participation for completed offences

\begin{tabular}{|l|l|l|l|l|l|l|}
\hline & $\begin{array}{l}\text { Nuremberg } \\
\text { /Tokyo }\end{array}$ & $\begin{array}{l}\text { Control } \\
\text { Council Law } \\
\text { No. } 10\end{array}$ & ICTY/ICTR & SLSC & ECCC & ICC \\
\hline Planning & No & No & Yes & Yes & Yes & No \\
\hline Ordering & No & Yes & Yes & Yes & Yes & Yes \\
\hline Inducing & No & No & No & No & No & Yes \\
\hline Soliciting & No & No & No & No & No & Yes \\
\hline Instigating & Yes & No & Yes & Yes & Yes & No \\
\hline $\begin{array}{l}\text { Co- } \\
\text { perpetration }\end{array}$ & No & No & No & No & No & jointly's \\
\hline Complicity & No & No & Only genocide & No & No & No \\
\hline Participate & No & No & No & No & Yesly genocide & No \\
\hline $\begin{array}{l}\text { Aiding, } \\
\text { abetting }\end{array}$ & 'Accomplices' & $\begin{array}{l}\text { 'Accessory or } \\
\text { abetted' } \\
\text { 'Took a } \\
\text { consenting part }\end{array}$ & Yes & Yes & Yes \\
\hline $\begin{array}{l}\text { Accessory after } \\
\text { the fact }\end{array}$ & No & 'Accessory' & 'Committed' & 'Committed' & 'Committed' & No \\
\hline $\begin{array}{l}\text { Joint Criminal } \\
\text { Enterprise }\end{array}$ & 'Common plan' & $\begin{array}{l}\text { 'Was connected } \\
\text { with' }\end{array}$ & 'Committed' & 'Committed' & 'Committed' & $\begin{array}{l}\text { 'Common } \\
\text { purpose' }\end{array}$ \\
\hline $\begin{array}{l}\text { Command } \\
\text { or superior } \\
\text { responsibility }\end{array}$ & $\begin{array}{l}\text { 'Leaders } \\
\text { organizers' }\end{array}$ & $\begin{array}{l}\text { 'High position' } \\
\text { Only crimes } \\
\text { against peace }\end{array}$ & Yes & Yes & Yes & Yes \\
\hline Membership & No & Yes & No & No & No \\
\hline
\end{tabular}

49 Personally committing has been defined as follows: 'the physical perpetration of a criminal act or the culpable omission of an act that was mandated by a rule of criminal law' while the person 'must have acted with the intent to commit the crime, or with an awareness of the substantial likelihood that the crime would occur as a consequence of his or her conduct', see: Judgment, Tadić (IT-94-1-A), Appeals Chamber, 15 July 1999, \$ 188 and Judgement, Kaing Guek Eav alias Duch (Case File 001/18-07-2007/ECCC/TC), Trial Chamber, 26 July 2010, $\$ \$ 480-481$; direct participation can also be found in a situation where the conduct of the accused was as much an integral part of the crimes as the crimes it enabled, see: Judgment, Gacumbitsi, (ICTR-200164-A), Appeals Chamber, 7 July 2006, \$ 161; Judgment, Ndindabahizi, (ICTR-01-71-A), Appeals Chamber, 16 January 2007, $\$ 123$; Judgment, Kalimanzira (ICTR-05-88-A), Appeals Chamber, 20 October 2010, § 219; Judgment, Kanyarukiga (ICTR-02-78), Trial Chamber, 1 November 2010, § 622; Judgment, Munyakazi (ICTR-97-36A-A), Appeals Chamber, 28 September 2011, § 135; Judgment, Karemera et al. (ICTR-98-44-T), Trial Chamber, 2 February 2012, $\$ 1606$. 
Some of the concepts set out above overlap in meaning; for instance, it has been said that the term 'inducing' in the ICC Statute is synonymous with 'incitement' while the terms 'solicit' and 'instigate' are similar. ${ }^{50}$ On the other hand, with respect to the ICC Statute, commentators have indicated that accessory after the fact is not part of this instrument. ${ }^{51}$ Some concepts, such as inducing, initiation and execution have not been subject to judicial interpretation as of yet.

As domestic courts have for the most part relied on the existing modes of liability in their own criminal codes, ${ }^{52}$ this part of the article will be limited to a discussion of some of the forms of extended liability at the international level and then only those theories which have been used against persons with high levels of influence. These forms of liability are command responsibility, joint criminal enterprise and perpetration, which correspond chronologically with the prevalent types of accountability utilized by international

50 Schabas, The International Criminal Court: A Commentary of the Rome Statute (OUP 2010) pp. 432-433. Cryer et. al., An Introduction to International Criminal Law and Procedure, 3rd Edition (CUP 2014) p. 375, are of the view that 'instigation' is largely the same as 'soliciting' or 'inducing'; see also Decision of the Confirmation of Charges, Gbagbo (ICC-02/11-01/11), June 12, 2014, $\$$ 243.

51 Schabas, op. cit., p. 435; Eser, Individual Criminal Responsibility in The Rome Statute of the International Criminal Court: A Commentary, Volume I, eds. Cassese, Gaeta and Jones (OUP 2002) pp. 806-807; however, see, in the context of common purpose, Judgment, Chui, Concurring Opinion of Judge Christine Van den Wyngaert (ICC-01/04-02/12), Trial Chamber, 18 December 2012, $\$ \$ 286-287$.

52 For an analysis of concepts of extended liability in national legal systems see: Eser, 'Individual Criminal Responsibility', in A. Cassese, P. Gaeta and J.R.W.D. Jones (eds.), The Rome Statute of the International Criminal Court: A Commentary, Volume I (OUP 2002) at 781-783; van Sliedregt, Individual Criminal Responsibility in International Law (OUP 2012) pp. 61-89, 8991, 95-96, 102-104, 110, 112-119 and 131-133; Ambos 2013, op. cit., pp. 114-117; Currie \& Rikhof 2013, op. cit., pp. 272-278; Eldar, Exploring International Criminal Law's Reluctance to Resort to Modalities of Group Responsibility: Five Challenges to International Prosecutions and their Impact on Broader Forms of Responsibility, 11 Journal of International Criminal Justice (2013) pp. 331-349; Muñoz-Conde \& Olásolo, The Application of the Notion of Indirect Perpetration through Organized Structures of Power in Latin America and Spain, 9 Journal of International Criminal Justice (2011) pp. 113-135; Ambos, The Fujimori Judgment: A President's Responsibility for Crimes Against Humanity as Indirect Perpetrator by Virtue of an Organized Power Apparatus, 9 Journal of international Criminal Justice (2011) pp. 137-158. 
Joseph Rikhof

institutions, namely the post Second World War tribunals, the ICTY/ICTR/SLSC, and the ICC respectively. ${ }^{53}$

\subsection{Command Responsibility}

A superior will be subject to individual criminal liability if the following elements exist: a superior-subordinate relationship; the superior knew or had reason to know that a criminal act was about to be, was being or had been committed, and failure to take necessary and reasonable measures to prevent or punish the conduct in question. ${ }^{54}$

53 For recent academic commentary regarding other forms of liability, see: Finnin, Elements of Accessorial Modes of Liability; Article 25(3)(b) and (c) of the Rome Statute of the International Criminal Court (Martinus Nijhoff Publishers 2012) pp. 60-72; Agbor, The Substantial Contribution Requirement: The Unfortunate Outcome of an Illogical Construction and Incorrect Understanding of Article 6(1) of the Statute of the ICTR, 12 International Criminal Law Review (2012) pp. 155-191; Agbor, The Problematic Jurisprudence on Instigation under the Statute of the ICTR: The Consistencies, Inconsistencies and Misgivings of the Trial and Appeal Chambers of the ICTR, 13 International Criminal Law Review, (2013) pp. 429-472; Stewart, The End of 'Modes of Liability' for International Crimes, 25 Leiden Journal of International Law (2012) pp. 165-219; Goy, Individual Criminal Responsibility before the International Criminal Court A Comparison with the Ad Hoc Tribunals, 12 International Criminal Law Review (2012) pp. 1-70; Currie \& Rikhof 2013, op. cit., pp. 645-652; Ambos and Njikam, Charles Taylor's Criminal Responsibility, 11 Journal of International Criminal Justice (2013) pp. 789-812; DeFalco, Contextualizing Actus Reus under Article 25(3)(d) of the ICC Statute: Thresholds of Contribution, 11 Journal of International Criminal Justice (2013) pp. 715-735; Vest, Problems of Participation - Unitarian, Differentiated Approach, or Something Else?, 12 Journal of International Criminal Justice (2014) pp. 295-309, Stuckenberg, Problems of 'Subjective Imputation' in Domestic and International Criminal Law, 12 Journal of International Criminal Justice (2014) at 311-323.

54 For an overview of the jurisprudence after the Second World War, see: Law Reports of Trials of War Criminals, Volume XV at 65-76, Ambos 2013, op. cit., pp. 108-110. For contemporary decisions, see: Judgment, Orić (IT-03-68-A), Appeals Chamber, 3 July 2008, \$ 18; Judgment, Hategekimana (ICTR-00-55B-T), Trial Chamber, 6 December 2010, \$ 653; Judgment, Gotovina et al. (IT-06-90-T), Trial Chamber, 15 April 2011, \$ 1962; Judgment, Setako (ICTR-04-81-A), 28 September 2011, \$269; Judgment, Karemera et al. (ICTR-98-44-T), Trial Chamber, 2 February 2012, \$ 1493; Judgment, Nizeyimana (ICTR-2000-55C), Trial Chamber, 19 June 2012, \$1475; Judgment, Taylor (SCSL-03-01-T), Trial Chamber, 18 May 2012, \$ 490; Judgment, Gotovina and Markač (IT-06-90-A), Appeals Chamber, 16 November 2012, \$128; Judgment, Stanišić and Župljanin (IT-08-91-T), Trial Chamber, 27 March 2013, \$\$ 109-110; Judgment, Prlić et al. (IT04-74), Trial Chamber, 29 May 2013, $\$ 237$. At the ICC, see the more detailed description in article 28 of its Statute; its interpretation in Decision of the Confirmation of Charges, Bemba (ICC-01/05-01/08),Pre-Trial Chamber II, 15 June 2009, $\$ \$ 408-448$ (following closely the ICTY/ ICTR jurisprudence), as well as Decision of the Confirmation of the Charges, Ntaganda (ICC01/04-02/06, June 9, 2014, $\$ 164$. For recent academic commentary, see: Sander, Unravelling the Confusion Concerning Successor Superior Responsibility in the ICTY Jurisprudence, 23 Leiden Journal of International Law (2010), pp. 105-135; van Sliedregt 2012, op. cit. at note 53 above, pp. 187-202; Ambos 2013, op. cit., pp. 197-232; Robinson, The Puzzle of Command Responsibility, Culpability and Causation: A Problem, the Arguments that Obscure It, and a Liberal Analysis, 13 Melbourne Journal of International Law (2012) pp. 1-58. 
A superior-subordinate relationship exists where a superior has effective control over a sub-ordinate, which means that the superior has the material ability to prevent or punish the sub-ordinate's criminal conduct. ${ }^{55}$ Superior responsibility can arise by virtue of the superior's de jure or de facto power over the relevant subordinate. ${ }^{56}$ The possession of $d e$ jure power may not suffice for the finding of superior responsibility if it does not manifest itself in effective control ${ }^{57}$ or if it only amount to influence. ${ }^{58} \mathrm{~A}$ superior cannot incur responsibility for crimes committed by a subordinate before he assumed his position as superior. ${ }^{59}$ The superior-subordinate relationship need not be of a permanent nature, but

55 Judgment, Orić (IT-03-68-A), Appeals Chamber, 3 July 2008, § 20; Judgment, Gotovina et al. (IT-06-90-T), Trial Chamber, 15 April 2011, \$1963; Judgment, Ndindiliyimana et al. (ICTR00-56-T), Trial Chamber, 17 May 2011, \$ 1917; Judgment, Nyiramasuhuko et al. (ICTR-9842-T), Trial Chamber, 24 June 2011, $\$ 5647$; Judgment, Perišić (IT-04-81-T), Trial Chamber, 6 September 2011, \$\$ 140 and 147-148; Judgment, Bagosora and Sengiyumva (ICTR-98-41-A), Appeals Chamber, 14 December 2011, \$ 642; Judgment, Karemera et al. (ICTR-98-44-T), Trial Chamber, 2 February 2012, $\$ \$ 1495-1496$; Judgment, Stanišić and Župljanin (IT-08-91-T), Trial Chamber, 27 March 2013, \$111; Judgment, Prlić et al. (IT-04-74), Trial Chamber, 29 May 2013, $\$ \$ 241$ and 244; Judgment, Ndindiliyimana et al. (ICTR-00-56-A), Appeals Chamber, $\$ 378$. In the Rwandan context it was held that a priest could have effective control, see Judgment, Nsengimana (ICTR-01-69-T), Trial Chamber, 17 November 2009, $\$ \$ 819-828$.

56 Judgment, Mucić et al. (Čelebići Camp') (IT-96-21), Trial Chamber, 16 November 1998, \$\$ 195197; Judgment, Ndahimana (ICTR-01-68), Trial Chamber, 30 December 2011, § 726; Judgment, Nizeyimana (ICTR-2000-55C), Trial Chamber, 19 June 2012, \$ 1476; Judgment, Taylor (SCSL03-01-T), Trial Chamber, 18 May 2012, \$ 493; Judgment, Prlić et al. (IT-04-74), Trial Chamber, 29 May 2013, § 242.

57 Judgment, Halilović (IT-01-48-A), Appeals Chamber, 16 October 2007, \$ 204; Judgment, Hategekimana (ICTR-00-55B-T), Trial Chamber, 6 December 2010, \$ 654; Judgment Nyiramasuhuko et al. (ICTR-98-42-T), Trial Chamber, 24 June 2011, \$ 5650-5651; Judgment, Perišić (IT-04-81-T), Trial Chamber, 6 September 2011, \$\$ 142-144; Judgment, Casimir Bizimungu et al. ( ICTR-99-50-T), Trial Chamber, 30 September 2011, \$ 1873; Judgment, Stanišić and Župljanin (IT-08-91-T), Trial Chamber, 27 March 2013, \$\$112-113.

58 Judgment, Casimir Bizimungu et al. (ICTR-99-50-T), Trial Chamber, 30 September 2011, $\$ \$$ 1891-1893; Judgment, Nizeyimana (ICTR-2000-55C), Trial Chamber, 19 June 2012, \$1476; Judgment, Taylor (SCSL-03-01-T), Trial Chamber, 18 May 2012, $\$ 493$.

59 Decision on Interlocutory Appeal Challenging Jurisdiction in Relation to Command Responsibility, Hadžihasanović et al. (IT-01-47-AR72), Appeals Chamber, 16 July 2003, \$\$ 37-56; Judgment, Halilović (IT-01-48-A), Appeals Chamber, 16 October 2007, § 67; Judgment Ndindiliyimana et al. (ICTR-00-56-T), Trial Chamber, 17 May 2011, \$ 1960; Judgment Nyiramasuhuko et al. (ICTR-98-42-T), Trial Chamber, 24 June 2011, $\$ 5646$; Judgment, Karemera et al. (ICTR-98-44-T), Trial Chamber, 2 February 2012, \$1492; Judgment, Stanišić and Župljanin (IT-08-91-T), Trial Chamber, 27 March 2013, $\$ 114$. For the opposite view, see: Judgment, Sesay, Kallon and Gbao ('RUF') (SCSL-04-15-T), Trial Chamber, 2 March 2009, \$\$ 294-306, which was overruled on appeal in Judgment, Sesay, Kallon and Gbao ('RUF'), SCSL-0414-A, Appeals Chamber, 26 October 2009, $\$ 874$. 
instead could arise on an ad hoc or temporary basis. ${ }^{60} \mathrm{~A}$ superior may however incur superior responsibility no matter how far down the chain of authority the subordinate may be and even if the subordinate has participated in the crimes through intermediaries. ${ }^{61}$ A superior does not necessarily need to know the exact identity of the subordinates who perpetrated the crimes in order to incur liability. ${ }^{62}$

With respect to the second requirement, this element is fulfilled if a superior knew or had reason to know that a subordinate's criminal act had been carried out, was taking place or was about the happen. ${ }^{63} \mathrm{~A}$ superior had reason to know only if information was available to him, which would have put him on notice of offences committed by subordinates. ${ }^{64}$ The 'reason to know standard' is met if the superior possessed information sufficiently alarming to justify further inquiry. ${ }^{65}$

60 Judgment Nyiramasuhuko et al. (ICTR-98-42-T), Trial Chamber, 24 June 2011, § 5648; Judgment, Perišić (IT-04-81-T), Trial Chamber, 6 September 2011, \$138; Judgment, Stanišić and Župljanin (IT-08-91-T), Trial Chamber, 27 March 2013, § 114.

61 Judgment, Orić (IT-03-68-A), Appeals Chamber, 3 July 2008, $\$ 20$; Judgment Nyiramasuhuko et al. (ICTR-98-42-T), Trial Chamber, 24 June 2011, \$ 5649; Judgment, Perišić (IT-04-81-T), Trial Chamber, 6 September 2011, $\$$ 145; Judgment, Casimir Bizimungu et al. ( ICTR-9950-T), Trial Chamber, 30 September 2011, \$\$1874-1875; Judgment, Karemera et al. (ICTR-9844-T), Trial Chamber, 2 February 2012, § 1497; Judgment, Nizeyimana (ICTR-2000-55C), Trial Chamber, 19 June 2012, \$ 1477; Judgment, Taylor (SCSL-03-01-T), Trial Chamber, 18 May 2012, $\$$ 494; Judgment, Stanišić and Župljanin (IT-08-91-T), Trial Chamber, 27 March 2013, \$114; see also Sliedregt 2012, op. cit., pp. 189-191 and 194.

62 Judgment, Bizimungu (ICTR-00-56B-A), Appeals Chamber, June 30, 2014, \$79.

63 Judgment, Kordić and Čerkez (IT-95-14/2-A), Appeals Chamber, 17 December 2004, \$ 839; Judgment, Gotovina et al. (IT-06-90-T), Trial Chamber, 15 April 2011, § 1964; Judgment Ndindiliyimana et al. (ICTR-00-56-T), Trial Chamber, 17 May 2011, \$\$1197-1198 and 1919120; Judgment, Perišić (IT-04-81-T), Trial Chamber, 6 September 2011, \$ 150; Judgment, Bagosora and Sengiyumva (ICTR-98-41-A), Appeals Chamber, 14 December 2011, \$642; Judgment, Ndahimana (ICTR-01-68), Trial Chamber, 30 December 2011, \$\$ 727-728; Judgment, Ntabakuze (ICTR-98-41A-A), Appeals Chamber, 8 May, 2012, \$248; Judgment, Taylor (SCSL-03-01-T), Trial Chamber, 18 May 2012, \$\$ 497-498; Judgment, Stanišić and Župljanin (IT-08-91-T), Trial Chamber, 27 March 2013, \$115.

64 Judgment, Krnojelac (IT-97-25-A), Appeals Chamber, 17 September 2003, \$ 156; Judgment, Perišić (IT-04-81-T), Trial Chamber, 6 September 2011, \$\$ 152-153; Judgment, Karemera et al. (ICTR-98-44-T), Trial Chamber, 2 February 2012, $\$ \$ 1498-1499 ;$ Judgment, Stanišić and Župljanin (IT-08-91-T), Trial Chamber, 27 March 2013, \$ 115; Judgment, Prlić et al. (IT-0474), Trial Chamber, 29 May 2013, $\$ \$ 247-249$; Judgment, Ndindiliyimana et al. (ICTR-00-56-A), Appeals Chamber, $\$ \$ 396-397$.

65 Judgment, Strugar (IT- IT-01-42A), Appeals Chamber, 17 July 2008, § 298; Judgment, Popović et al. (IT-05-88-T), Trial Chamber, 10 June 2010, \$1041; Judgment, Đorđević (IT-05-87/1), Trial Chamber, 23 February 2011, $\$ 1886$; Judgment, Hategekimana (ICTR-00-55B-T), Trial Chamber, 6 December 2010, $\$$ 655-656; Judgment, Perišić (IT-04-81-T), Trial Chamber, 6 September 2011, $\$ 151$; Judgment, Stanišić and Župljanin (IT-08-91-T), Trial Chamber, 27 March 2013, § 115; Judgment, Prlić et al. (IT-04-74), Trial Chamber, 29 May 2013, $\$ 250$. 
With respect to the third requirement, necessary measures means appropriate action, which show that the superior genuinely tried to prevent before the commission of acts by sub-ordinates or punish after such crimes ${ }^{66}$ while reasonable measures are those reasonably falling within the material powers of the superior. ${ }^{67} \mathrm{~A}$ superior is not expected to perform the impossible but must use every means within his ability. ${ }^{68}$ Such measures may include carrying out an investigation, transmitting information in a superior's possession to the proper administrative or prosecutorial authorities, issuing special orders aimed at bringing unlawful practices of subordinates in compliance with the rules of war, protesting against or criticizing criminal action, reporting the matter to the competent authorities or insisting before a superior authority that immediate action be taken. ${ }^{69}$ Decision of the Confirmation of Charges, Gbagbo (ICC-02/11-01/11), June 12, 2014, $\$ 264$; Judgment, Bizimungu (ICTR-00-56B-A), Appeals Chamber, June 30, 2014, § 133.

See: Judgment, Orić (IT-03-68-A), Appeals Chamber, 3 July 2008, \$ 177; Judgment, Gotovina et al. (IT-06-90-T), Trial Chamber, 15 April 2011, $\$ 1965$; Judgment Ndindiliyimana et al. (ICTR00-56-T), Trial Chamber, 17 May 2011, \$1953 and 2008; Judgment, Bagosora and Sengiyumva (ICTR-98-41-A), Appeals Chamber, 14 December 2011, \$683; Judgment, Ndahimana (ICTR-0168), Trial Chamber, 30 December 2011, $\$ \$ 761,763$; Judgment, Karemera et al. (ICTR-98-44-T), Trial Chamber, 2 February 2012, \$1500; Judgment, Taylor (SCSL-03-01-T), Trial Chamber, 18 May 2012, $\$ \$ 500-501$; Judgment, Stanišić and Župljanin (IT-08-91-T), Trial Chamber, 27 March 2013, \$ 116; Judgment, Prlić et al. (IT-04-74), Trial Chamber, 29 May 2013, $\$ \$ 254-261$.

68 Judgment, Popović et al. (IT-05-88-T), Trial Chamber, 10 June 2010, \$ 1043; Judgment, Đorđević (IT-05-87/1), Trial Chamber, 23 February 2011, \$ 1887; Judgment, Perišić (IT-04-81-T), Trial Chamber, 6 September 2011, $\$ 157$; Judgment, Stanišić and Župljanin (IT-08-91-T), Trial Chamber, 27 March 2013, \$116.

69 Judgment, Popović et al. (IT-05-88-T), Trial Chamber, 10 June 2010, \$ 1045; Judgment, Đorđević (IT-05-87/1), Trial Chamber, 23 February 2011, $\$ \$ 1888-1890$; Judgment, Gotovina et al. (IT06-90-T), Trial Chamber, 15 April 2011, \$ 1965; Judgment, Perišić (IT-04-81-T), Trial Chamber, 6 September 2011, $\$ \$ 158-160$; Judgment, Karemera et al. (ICTR-98-44-T), Trial Chamber, 2 February 2012, \$1501; Judgment, Taylor (SCSL-03-01-T), Trial Chamber, 18 May 2012, \$502; Judgment, Stanišić and Župljanin (IT-08-91-T), Trial Chamber, 27 March 2013, § 117. 
Joseph Rikhof

\subsection{Joint Criminal Enterprise}

The ICTY jurisprudence has distinguished three types of JCE. ${ }^{70}$ In the first form of joint criminal enterprise, all of the co-perpetrators possess the same intent to effect the common purpose, namely the crime. ${ }^{71}$ The second form of joint criminal enterprise, the 'systemic' form, a variant of the first form, is characterized by the existence of an organized criminal system, in particular in the case of concentration or detention camps. This form of joint criminal enterprise requires personal knowledge of the organized system and intent to further the criminal purpose of that system.

The third, 'extended' form of joint criminal enterprise entails responsibility for crimes committed beyond the common purpose, but which are nevertheless a natural and foreseeable consequence of the common purpose. The requisite mens rea for the extended form is twofold. First, the accused must have the intention to participate in and contribute to the common criminal purpose. Second, in order to be held responsible for crimes which were not part of the common criminal purpose, but which were nevertheless a natural and foreseeable consequence of it, the accused must also know that such a crime might be perpetrated by a member of the group, and willingly take the risk that the crime might occur by joining or continuing to participate in the enterprise. ${ }^{72}$

The general requirements for this type of responsibility are as follows:

- a plurality of persons, who do not need to be organized in a military, political or administrative structure;

- the existence of a common plan, design or purpose which amounts to or involves the commission of a crime. There is no necessity for this plan, design or purpose to have been previously arranged or formulated. The common plan or purpose may materi-

70 See: Judgment, Tadić (IT-94-1-A), Appeals Chamber, 15 July 1999, § 227; Judgment, Vasiljević (IT-98-32-A), Appeals Chamber, 25 February 2004, \$ 100; Judgment, Stakić (IT-97-24-A), Appeals Chamber, 22 March 2006, $\$ 64$. It is worth noting that in one of the first cases in which JCE was used, namely the Tadic case, the accused had been acquitted by the Trial Chamber since it could not be proven that he, as part of a larger group of five men, had played any part in the commission of murder. The Appeals Chamber found that there was criminal liability based on JCE even if there was no proof of the personal commission of any of the members in the JCE; see for more details, Darcy, Collective Responsibility and Accountability Under International Law (Transnational Publishers 2007) pp. 227-228. For an subsequent detailed analysis that the Tadić case had correctly considered JCE to be part of customary international law, see Judgment, Đorđević (IT-05-87/1-A), Appeals Chamber, 27 January 2014, \$\$ 32-58.

71 Judgment, Haradinaj et al. (IT-04-84bis-T), Trial Chamber, 29 November 2012, \$620.

72 Judgment, Haradinaj et al. (IT-04-84bis-T), Trial Chamber, 29 November 2012, \$ 621; Judgment, Tolimir (IT-05-88/2-T), Trial Chamber, 12 December 2012, $\$ \$ 888$ and 897; Judgment, Prlić et al. (IT-04-74), Trial Chamber, 29 May 2013, \$\$ 203-204; Judgment, Stanišić and Simatović (IT-0369-T), Trial Chamber, 30 May 2013, \$ 1255-1257; Judgment, Đorđević (IT-05-87/1-A), Appeals Chamber, 27 January 2014, $\$ \$ 468$ and 474. 
alise extemporaneously and be inferred from the fact that a plurality of persons acts in unison to put into effect a joint criminal enterprise;

- participation of the accused in the common design involving the perpetration of one of the international crimes. This participation need not involve commission of a specific crime under one of those provisions but may take the form of assistance in, or contribution to, the execution of the common plan or purpose; the participation in the enterprise must be significant, meaning an act or omission that makes an enterprise efficient or effective; e.g. a participation that enables the system to run more smoothly or without disruption. ${ }^{73}$

More recently, some refinements and clarifications have been made to these general principles. $^{74}$

73 Judgment, Tadić (IT-94-1-A), Appeals Chamber, 15 July 1999, § 227; Judgment, Vasiljević (IT98-32-A), Appeals Chamber, 25 February 2004, \$100; Judgment, Stakić (IT-97-24-A), Appeals Chamber, 22 March 2006, $\$ 64$; Judgment, Hategekimana (ICTR-00-55B-T), Trial Chamber, 6 December 2010, \$ 649-650; Judgment, Gatete (ICTR-2000-61-T), Trial Chamber, 31 March 2011, \$\$ 577-579; Judgment, Gotovina et al. (IT-06-90-T), Trial Chamber, 15 April 2011, \$19501954; Judgment, Casimir Bizimungu et al. ( ICTR-99-50-T), Trial Chamber, 30 September 2011, $\$ \$ 1906-1909$; Judgment, Ndahimana (ICTR-01-68), Trial Chamber, 30 December 2011, $\$ 721$; Judgment, Karemera et al. (ICTR-98-44-T), Trial Chamber, 2 February 2012, \$1436; Judgment, Nizeyimana (ICTR-2000-55C), Trial Chamber, 19 June 2012, $\$ \$ 1454-1456$; Judgment, Taylor (SCSL-03-01-T), Trial Chamber, 18 May 2012, \$\$ 457-463; Judgment, Gatete (ICTR-2000-61-A), Appeals Chamber, 9 October 2012, $\$ \$ 239,241$; Judgment, Haradinaj et al. (IT-04-84bis-T), Trial Chamber, 29 November 2012, \$618-619; Judgment, Tolimir (IT-05-88/2-T), Trial Chamber, 12 December 2012, $\$ \$ 889-890$; Judgment, Ngirabatware (ICTR-99-54-T), Trial Chamber, 20 December 2012, \$ 1300; Judgment, Stanišić and Župljanin (IT-08-91-T), Trial Chamber, 27 March 2013, $\$ \$ 101-103$; Judgment, Prlić et al. (IT-04-74), Trial Chamber, 29 May 2013, $\$ \$ 212-$ 216; Judgment, Stanišić and Simatović (IT-03-69-T), Trial Chamber, 30 May 2013, § 1258.

74 This might have been the result of criticism raised in the academic literature where this form of liability, especially the extended variety, has been controversial; see for instance: Schabas, Mens Rea and the International Tribunal for the Former Yugoslavia, 37 New England Law Review (2003) pp. 1030-1036; Powles, 'Joint Criminal Enterprise: Criminal Liability by Prosecutorial Ingenuity and Judicial Creativity?, 2 Journal of International Criminal Justice (2004) pp. 606616; Marston Danner \& Martinez, Guilty Associations: Joint Criminal Enterprise, Command Responsibility, and the Development of International Criminal Law, 93 California Law Review (2005) pp. 133-137; Fletcher \& Ohlin, Relearning Fundamental Principles of Criminal Law in the Darfur Case, 3 Journal of International Criminal Justice (2005) pp. 548-550; Ramer, Joint Criminal Enterprise Liability and Persecution, 7 Chicago-Kent Journal of International and Comparative Law (2007) pp. 58-61; Darcy, Collective Responsibility and Accountability Under International Law (Transnational Publishers 2007) pp. 245-253;Robinson, The Identity Crisis of International Criminal Law, 21 Leiden Journal of International Law (2008) pp. 938-943; Damgaard, Individual Criminal Responsibility for Core International Crimes, Selected Pertinent Issues (Springer Verlag 2008) pp. 207-211 and 236-261; Ohlin, Joint Intentions to Commit International Crimes, 11 Chicago Journal of International Law (2010-2011) pp. 693-753; van Sliedregt 2012, op.cit., pp. 141-142; van Sliedregt, The Curious Case of International Criminal Liability, 10 Journal of International Criminal Justice (2012) pp. 1171-1188. 
In general, the doctrine of joint criminal enterprise can be used against high level functionaries ${ }^{75}$ and is not restricted to small-scale cases but can also apply to large criminal enterprises. ${ }^{76}$ Conversely, where the common purpose includes crimes committed over a wide geographical area, a person may be found criminally responsible for his participation in the enterprise, even if his contributions to the enterprise occurred only in a much smaller geographical area. ${ }^{77}$

With respect to the first two categories, it has been made clear that mere membership in the group having a common criminal purpose is not sufficient, ${ }^{78}$ although an omission can amount to JCE participation..$^{79}$ However, it is not required that each member in the JCE is identified by name but it can be sufficient to refer to categories or groups of persons. ${ }^{80}$

The common criminal objective of the JCE may also evolve over time, as long as the members agreed on this expansion of means. It means that the crimes that make up the common purpose may evolve and change over time and as such the JCE may have different participants at different times. ${ }^{81}$

It is not necessary that the persons carrying out the actus reus of the crime forming part of the common purpose have been participants in or members of the JCE. Consequently, persons carrying out the crime need not share the intent of the crime with the participants in the common purpose. Nor is the mental state of persons carrying out the crime a determinative factor in finding the requisite intent for the participants in a JCE. But if a JCE member used a non-member to commit a crime, that crime must be traced

75 Judgment, Krajišnik, (IT-00-39-A), Appeals Chamber, 17 March 2009, § 194.

76 Judgment, Brđanin (IT-99-36-A), Appeals Chamber, 3 April 2007, $\$ 425$. For a commentary of the theory of interlinked JCE coming out of this decision, see van Sliedregt 2012, op.cit., pp. 158165 and 181-182.

77 Judgment, Tadić (IT-94-1-A), Appeals Chamber, 15 July 1999, § 199; Judgment, Popović et al. (IT-05-88-T), Trial Chamber, 10 June 2010, $\$ 1024$.

78 Judgment, Brđanin (IT-99-36), Trial Chamber, 1 September 2004, $\$ 263$; Judgment, Karemera et al. (ICTR-98-44-T), Trial Chamber, 2 February 2012, \$ 1437.

79 Judgment, Ndahimana (ICTR-01-68), Trial Chamber, 30 December 2011, \$\$ 810-811; Judgment, Haradinaj et al. (IT-04-84bis-T), Trial Chamber, 29 November 2012, \$619.

80 Judgment, Krajišnik, (IT-00-39-A), Appeals Chamber, 17 March 2009, \$ 156; Judgment, Đorđević (IT-05-87/1), Trial Chamber, 23 February 2011, \$ 1862; Judgment, Haradinaje et al. (IT-04-84bis-T), Trial Chamber, 29 November 2012, \$ 617; Judgment, Đorđević (IT-05-87/1-A), Appeals Chamber, 27 January 2014, \$\$ 127-130.

81 Judgment, Krajišnik, (IT-00-39-A), Appeals Chamber, 17 March 2009, § 163; Judgment, Đorđević (IT-05-87/1), Trial Chamber, 23 February 2011, \$ 1862; Special Tribunal for Lebanon, Interlocutory Decision on the Applicable Law: Terrorism, Conspiracy, Homicide, Perpetration, Cumulative charging, STL-II-OI/I/AC/RI76bis, Appeals Chamber, 16 February 2011, \$\$ 246-248; Judgment, Taylor (SCSL-03-01-T), Trial Chamber, 18 May 2012, \$ 464; Judgment, Haradinaj et al. (IT-04-84bis-T), Trial Chamber, 29 November 2012, $\$ 618$; Judgment, Tolimir (IT-05-88/2-T), Trial Chamber, 12 December 2012, \$\$ 891-892; Judgment, Šainović et al. (IT05-87-A), Appeals Chamber, 23 January 2014, $\$ \$ 609-611$. 
back to the member of the JCE. ${ }^{82}$ For persons in a criminal enterprise to be liable it must be shown that they acted together, or in concert with each other, in the implementation of a common objective, ${ }^{83}$ but is not a legal requirement that they acted in unison. ${ }^{84}$

With respect to the contribution factor, the participation or contribution of an accused to the common purpose need not be substantive or criminal but it should at least be a significant contribution to the crimes committed. ${ }^{85}$ The fact that different persons might have different levels of involvement does not negate the existence of a JCE and a different level of involvement can be dealt with at the sentencing stage. ${ }^{86} \mathrm{~A}$ person's position of authority and silent approval militate in favour of a finding that his participation was significant, ${ }^{87}$ which includes a failure to ensure the investigation and punishment of crimes committed. ${ }^{88}$

82 Judgment, Krajišnik, (IT-00-39-A), Appeals Chamber, 17 March 2009, § 225-226; Judgment, Đorđević(IT-05-87/1), Trial Chamber, 23 February 2011, \$\$ 1864-1868; Judgment, Karemera et al. (ICTR-98-44-T), Trial Chamber, 2 February 2012, \$1438; Judgment, Stanišić and Župljanin (IT08-91-T), Trial Chamber, 27 March 2013, \$ 104; Judgment, Stanišić and Simatović (IT-03-69-T), Trial Chamber, 30 May 2013, \$ 1258; Judgment (Rule 98bis), Karadžić (IT -95-5/18-AR98bis.1), Appeals Chamber, 11 July 2013, \$79; Judgment, Đordević (IT-05-87/1-A), Appeals Chamber, 27 January 2014, $\$ \$ 165,169$ and 171; Judgement, Šainović et al. (IT-05-87-A), Appeals Chamber, 23 January 2014, \$\$1256-1257.

83 Judgment, Stanišić and Simatović (IT-03-69-T), Trial Chamber, 30 May 2013, § 1259.

84 Judgment, Đorđević (IT-05-87/1-A), Appeals Chamber, 27 January 2014, \$\$ 138-142.

85 Judgment, Krajišnik, (IT-00-39-A), Appeals Chamber, 17 March 2009, §215; Judgement, Šainović et al. (IT-05-87-A), Appeals Chamber, 23 January 2014, $\$ \$ 985$ and 987.This implies a lesser level of contribution for JCE as compared to aiding and abetting according to: Judgment, Gotovina and Markač (IT-06-90-A), Appeals Chamber, 16 November 2012, \$\$ 147 and 149; Judgment, Haradinaj et al. (IT-04-84bis-T), Trial Chamber, 29 November 2012, \$619; Judgment, Tolimir (IT-05-88/2-T), Trial Chamber, 12 December 2012, \$\$ 893-894; Judgment, Prlić et al. (IT-0474), Trial Chamber, 29 May 2013, § 221; Judgment, Stanišić and Simatović (IT-03-69-T), Trial Chamber, 30 May 2013, $\$ 1258$. On this issue, see: Boas, Bischoff \& Reid, Forms of Responsibility in International Criminal Law (CUP 2007) pp. 422-423; Robinson 2008, op. cit. at note 75, pp. 925-963 at 939.

86 Judgment, Brđanin (IT-99-36-A), Appeals Chamber, 3 April 2007, § 432; Judgment, Đorđević (IT-05-87/1), Trial Chamber, 23 February 2011, $\$ 1863$.

87 Judgment, Tolimir (IT-05-88/2-T), Trial Chamber, 12 December 2012, \$ 894; Judgement, Šainović et al. (IT-05-87-A), Appeals Chamber, 23 January 2014, \$\$ 1242 and 1368.

88 Judgment, Đorđević (IT-05-87/1-A), Appeals Chamber, 27 January 2014, \$\$ 454 and 460; Judgement, Šainović et al. (IT-05-87-A), Appeals Chamber, 23 January 2014, \$\$ 1233-1234. 
Joseph Rikhof

\section{With respect to the third category of JCE a person}

can only be held responsible for a crime outside the common purpose, if under the circumstances of the case: (i) it was foreseeable that such a crime might be perpetrated by one or othermembers of the group and (ii) the accused willingly took that risk (dolus eventualis). The crime must be shown to have been foreseeable to the accused in particular. $^{89}$

Willingly taking a risk means a decision to participate in a JCE with the awareness that crime was a possible (not probable) consequence of the implementation of that enterprise. ${ }^{90}$ For third category JCE liability, the accused does not need to possess the requisite intent for the crime falling outside the common purpose. This also applies to specific intent crimes. The mental state of the person or persons carrying out the extended crime is not relevant for the finding of the mental state of the accused, but is determinative to the finding of which extended crime was committed. ${ }^{91}$

A JCE can also be a basis for liability in genocide, including the third category. ${ }^{92}$

JCE has been used outside the ICTY/ICTR context in the proceedings of the Sierra Leone Special Court ${ }^{93}$ as well in the Extraordinary Chambers in the Court of Cambodia, although in the latter institution it was decided that the third category was not part of

Judgment, Brdanin (IT-99-36-A), Appeals Chamber, 3 April 2007, §365; Judgment, Ngirabatware (ICTR-99-54-T), Trial Chamber, 20 December 2012, \$ 1302; Judgment, Đorđević (IT-0587/1-A), Appeals Chamber, 27 January 2014, \$ 906; Judgement, Šainović et al. (IT-05-87-A), Appeals Chamber, 23 January 2014, $\$ \$ 1281-1282,1525,1538$ and 1557.

$90 \quad$ Judgment, Brdanin (IT-99-36-A), Appeals Chamber, 3 April 2007, $\$ 411$; Judgment, Karemera et al. (ICTR-98-44-T), Trial Chamber, 2 February 2012, $\$ \$ 1463-1464$; Judgment, Gotovina and Markač (IT-06-90-A), Appeals Chamber, 16 November 2012, \$\$ 90 and 97; Judgment, Stanišić and Župljanin (IT-08-91-T), Trial Chamber, 27 March 2013, \$106; Judgment, Prlić et al. (IT-0474), Trial Chamber, 29 May 2013, \$220; Judgment, Đorđević (IT-05-87/1-A), Appeals Chamber, 27 January 2014, $\$ \$ 907,911-913$ and 926-927.

91 Judgment, Popović et al. (IT-05-88-T), Trial Chamber, 10 June 2010, $\$ 1031$.

92 Decision on Interlocutory Appeal, Brđanin (IT-99-36-A), Appeals Chamber), 19 March 2004, $\$ \$$ 5-10. However, see Special Tribunal for Lebanon, Interlocutory Decision on the Applicable Law: Terrorism, Conspiracy, Homicide, Perpetration, Cumulative charging, STL-II-OI/I/AC/RI76bis, Appeals Chamber, 16 February 2011, $\$ 249$ with respect to specific intent offences in general; as well in this respect see: Judgment, Ndahimana (ICTR-01-68), Trial Chamber, 30 December 2011, $\$ 722$; Judgment, Karemera et al. (ICTR-98-44-T), Trial Chamber, 2 February 2012, $\S$ 1439; Judgment, Taylor (SCSL-03-01-T), Trial Chamber, 18 May 2012, $\$ 468$; Judgment, Tolimir (IT-05-88/2-T), Trial Chamber, 12 December 2012, \$ 898; Judgment, Ngirabatware (ICTR-9954-T), Trial Chamber, 20 December 2012, \$ 1301; Judgment, Đorđević (IT-05-87/1-A), Appeals Chamber, 27 January 2014, $\$ \$ 77-84$ (the latter indicating the JCE III can be used for special intent crimes).

93 Judgment, Brima, Kamara and Kanu ('AFRC') (SCSL-2004-16-A), Appeals Chamber, 22 February 2008, $\$ \$ 72-86$ and Judgment, Sesay, Kallon and Gbao ('RUF'), SCSL-04-14-A), Appeals Chamber, 26 October 2009, $\$ \$ 295-306$ and 312-318. 
customary international law nor was it included in the law of Cambodia during the time for which the Chambers had jurisdiction, in the seventies. ${ }^{94}$

\subsection{Perpetration ${ }^{95}$}

According to the ICC jurisprudence, there are three forms of committing a crime as a perpetrator, namely where a person:

(a) physically carries out the objective elements of the offence (commission of the crime in person, or direct perpetration);

(b) has, along with others, control over the offence by reason of the essential tasks assigned to him or her (commission of the crime jointly with others, or co-perpetration); or c) controls the will of those who carry out the objective elements of the offence (commission of the crime through another person, or indirect perpetration). ${ }^{96}$

In addition, the distinction between principals and accessories in a situation with a plurality of persons can also be made along a spectrum, in which different aspects of the involvement are emphasized. If the objective manifestation of the crime (in that all the

94 Decision on the Appeals against the Co-Investigating Judges Order on Joint Criminal Enterprise (JCE), (Case File 002/19-09-2007-ECCC/OCIJ (PTC38), Pre-Trial Chamber, May 20, 2010, \$\$ 69-72 re JCE I and II and $\$ \$ 77,83$ and 87 . For JCE III; see also: Judgement, Kaing Guek Eav alias Duch (Case File 001/18-07-2007/ECCC/TC), Trial Chamber, 26 July 2010, paragraphs 504513; Decision on the Applicability of Joint Criminal Enterprise (Case File No. 002/19-09-2007/ ECCC/TC (Trial Chamber, September 12, 2011. For a commentary, see Karnavas, Joint Criminal Enterprise at the ECCC: A Critical Analysis of the Pre-Trial Chamber's Decision Against the Application of JCE III and two Divergent Commentaries on the Same, 21 Criminal Law Forum (2010), pp. 445-494.

95 For a comparison between JCE and perpetration, see Manacorda \& Meloni, Indirect Perpetration versus Joint Criminal Enterprise: Concurring Approaches in the Practice of International Criminal Law?, 9 Journal of International Criminal Justice (2011) pp. 159-178.

96 Decision on the Confirmation of Charges, Lubanga (ICC-01/04-01/06), Pre-Trial Chamber I, 29 January 2007, $\$ \$ 332$; Decision of the Confirmation of the Charges, Katanga and Chui (ICC No. ICC-01/04-01/07), Pre-Trial Chamber I, 30 September 2008, $\$ 488$ (which also developed the notion of indirect co-perpetration in $\$ \$ 491-493$; Decision of the Confirmation of the Charges, Garda (ICC-02/05-02/09), Pre-Trial Chamber I, 8 February 2010, \$153; Judgment, Chui, Concurring Opinion of Judge Christine Van den Wyngaert (ICC-01/04-02/12), Trial Chamber, 18 December 2012, was of the view that the notion of indirect perpetration, in so far it goes beyond perpetration through another person, was an unwarranted extension of article 25(3)(a) $(\$ \$ 58-64)$ as was the notion of a person's control over an organization ( $\$ \$ 49-57)$, which was repeated in Judgment, Katanga, Minority Opinion of Judge Christine Van den Wyngaert, ICC01/04-01/07, Trial Chamber, March 7, 2014, \$\$ 277-281 and in Partially Dissenting opinion of Judge Christine Van Den Wyngaert, Blé Goudé., (ICC-02/11-02/11-186-Anx), December 11, $2014, \S 5$. For a subsequent discussion regarding the notion of perpetration through another person, as well as direct perpetration, see Judgment, Katanga (ICC- ICC-01/04-01/07), Trial Chamber, March 7, 2014, $\$ \$ 1398-1416$. For a subsequent discussion of indirect co-perpetration, see Decision of the Confirmation of the Charges, Ntaganda (ICC-01/04-02/06, June 9, 2014, $\$ \$ 104,121$ and 136; see also van Sliedregt 2012, op.cit., at 165-171. 
elements are carried out by the same person) is the focal point of investigation this can be called an objective approach with a person liable as a principal. The subjective approach does not primarily examine the level of contribution but instead the shared intent to carry out a crime, which is done in the JCE or common purpose doctrine. Co-perpetration focuses on the degree of control carried out by a person who is removed from the scene of the crime but has control or is the mastermind behind the commission of the offences. ${ }^{97}$

The actus reus of co-perpetration is twofold: the existence of an agreement or common plan, ${ }^{98}$ which for a time had been possibly replaced by the requirement of shared

97 Decision on the Confirmation of Charges, Lubanga (ICC-01/04-01/06), Pre-Trial Chamber I, 29 January 2007, $\$ \$ 327-331$; Decision of Confirmation of Charges, Bemba (ICC-01/05-01/08), PreTrial Chamber II, 15 June 2009, $\$ \$ 346-347$; Corrigendum of the Decision on the Confirmation of Charges, Nourain and Jamus, (ICC-02/05-03/09), Pre-Trial Chamber I, 7 March 2011, $\$ 126$; Decision on the Prosecutor's Application for Summons to Appear for William Samoei Ruto, Henry Kiprono Kosgey and Joshua Arap Sang (ICC-01/09-01/11), Pre-Trial Chamber II, 8 March 2011, \$39. However, see Judgment, Chui, Concurring Opinion of Judge Christine Van den Wyngaert (ICC-01/04-02/12), Trial Chamber, 18 December 2012, \$ 6; Judgment, Katanga (ICC- ICC-01/04-01/07), Trial Chamber, March 7, 2014, $\$ \$ 1390-1397$. For a commentary on this jurisprudence see Jain, The Control Theory of Perpetration in International Criminal Law, 12 Chicago Journal of International Law (2011), pp. 159-200; Weigend, Perpetration Through an Organization: The Unexpected Career of a German Legal Concept, 9 Journal of International Criminal Justice (2011), pp. 91-111; Ohlin, Second-Order Linking Principles: Combining Vertical and Horizontal Modes of Liability, 25 Leiden Journal of International Law (2012), pp. 771-797; Wirth, Co-perpetration in the Lubanga Trial Judgment, 10 Journal of International Criminal Justice (2012) pp. 971-995; Ohlin, van Sliedregt \& Weigend, Assessing the Control-Theory, 26 Leiden Journal of International Law (2013) pp. 725-746; Ambos, Workshop, a Symposium and the Katanga Trial Judgment of 7 March 2014, 12 Journal of International Criminal Justice (2014) pp. 219-229; Weigend, Problems of Attribution in International Criminal Law: A German Perspective, 12 Journal of International Criminal Justice (2014) pp. 253-266; Cryer, Imputation and Complicity in Common Law States: A (Partial) View from England and Wales, 12 Journal of International Criminal Justice (2014) pp. 267-281; Ohlin, Searching for the Hinterman: In Praise of Subjective Theories of Imputation', 12 Journal of International Criminal Justice (2014) pp. 325343.

98 Decision on the Confirmation of Charges, Lubanga (ICC-01/04-01/06), Pre-Trial Chamber I, 29 January 2007, $\$ \$ 343-348$; Decision of the Confirmation of the Charges, Katanga and Chui (ICC No. ICC-01/04-01/07), Pre-Trial Chamber I, 30 September 2008, \$\$ 519-526; Decision of Confirmation of Charges, Bemba (ICC-01/05-01/08), Pre-Trial Chamber II, 15 June 2009, $\$ 350$; Decision of the Confirmation of the Charges, Garda (ICC-02/05-02/09), Pre-Trial Chamber I, 8 February 2010, \$160; Corrigendum of the Decision on the Confirmation of Charges, Nourain and Jamus, (ICC-02/05-03/09), Pre-Trial Chamber I, 7 March 2011, \$\$ 128-129, 136; Decision on the Prosecutor's Application for Summonses to Appear for Francis Kirimi Muthaura, Uhuru Muigai Kenyatta and Mohammed Hussein Ali (CC-01/09-02/11), Pre-Trial Chamber II, 8 March 2011, $\$ 36$; Decision on the Prosecutor’s Application for Summons to Appear for William Samoei Ruto, Henry Kiprono Kosgey and Joshua Arap Sang (ICC-01/09-01/11), Pre-Trial Chamber II, 8 March 2011, $\$ 40$; Judgment, Lubanga (ICC-01/04-01/06), Trial Chamber, 14 March 2012, \$\$ 989-999; Decision of the Confirmation of Charges, Gbagbo (ICC-02/11-01/11), June 12, 2014, $\$ 230$. Decision of the Confirmation of Charges, Blé Goudé, (ICC-02/11-02/11), December 11, $2014, \S 134$. 
intent ${ }^{99}$ between two or more persons; and the co-ordinated essential contribution ${ }^{100}$ by each of these persons resulting in the commission of a crime. With respect to the first of these requirements, the agreement does not have to be explicit nor does the plan have to be specifically directed at committing a crime but only if its implementation embodies a sufficient risk that, in the ordinary course of events, a crime will be committed. ${ }^{101}$ As to essential contribution, there is no need to establish presence at the scene of the crime or that there was a direct and physical link between the contribution and the commission of the crime. ${ }^{102}$ The essential contribution appeared to have been replaced by a different element, namely direct contribution but the original approach was restored by the first appeal decision in thie area. ${ }^{103}$

The mens rea of this type of liability has three aspects, namely the subjective element of the co-perpetrators with respect to underlying crime, secondly the fact that the co-perpetrators are all mutually aware and mutually accept that implementing their common plan may result in the realization of the objective elements of the crime and thirdly that Trial Chamber, 18 December 2012, $\$ \$ 32-35$.

100 Decision on the Confirmation of Charges, Lubanga (ICC-01/04-01/06), Pre-Trial Chamber I, 29 January 2007, $\$ \$ 343-348$; Decision of the Confirmation of the Charges, Katanga and Chui (ICC No. ICC-01/04-01/07), Pre-Trial Chamber I, 30 September 2008, \$\$ 519-526; Decision of Confirmation of Charges, Bemba (ICC-01/05-01/08), Pre-Trial Chamber II, 15 June 2009, §350; Decision of the Confirmation of the Charges, Garda (ICC-02/05-02/09), Pre-Trial Chamber I, 8 February 2010, \$160; Corrigendum of the Decision on the Confirmation of Charges, Nourain and Jamus, (ICC-02/05-03/09), Pre-Trial Chamber I, 7 March 2011, $\$ \$ 128-129,136$; Decision on the Prosecutor's Application for Summonses to Appear for Francis Kirimi Muthaura, Uhuru Muigai Kenyatta and Mohammed Hussein Ali (CC-01/09-02/11), Pre-Trial Chamber II, 8 March 2011, \$36; Decision on the Prosecutor's Application for Summons to Appear for William Samoei Ruto, Henry Kiprono Kosgey and Joshua Arap Sang (ICC-01/09-01/11), Pre-Trial Chamber II, 8 March 2011, $\$ 40$; Judgment, Lubanga (ICC-01/04-01/06), Trial Chamber, 14 March 2012, $\$ \$$ 989-999; Decision of the Confirmation of Charges, Gbagbo (ICC-02/11-01/11), June 12, 2014, § 230.

101 Judgment, Lubanga (ICC-01/04-01/06), Trial Chamber, 14 March 2012, $\$ \$$ 983-988.

102 Judgment, Lubanga (ICC-01/04-01/06), Trial Chamber, 14 March 2012, $\$ \$ 1004-1005$. Judgment Lubanga (ICC-01/04-01/06 A5) Appeals Chamber, 1 December 2014, $\$ 469$.

103 Judgment, Chui, Concurring Opinion of Judge Christine Van den Wyngaert (ICC-01/04-02/12), Trial Chamber, 18 December 2012, $\$ \$ 40-48$. Judgment, Lubanga (ICC-01/04-01/06 A5) Appeals Chamber, 1 December 2014, $\$ 469$. 
Joseph Rikhof

the persons are aware of the factual circumstances enabling them to jointly control the crime. $^{104}$

\subsection{Observations with respect to participation in international crimes}

The three types of liability discussed above, all have some peculiarities, apart from (or maybe because of) built-in legal obstacles, which have limited their application in a more general sense across all the international institutions.

Command responsibility was a main-stay in the charges in both international and national military tribunals after the Second World War but its importance diminished in its application by the ICTY, ICTR or ICC. Two factors seem to have contributed to this lack of interest in this form of liability at the two tribunals and the international court. The first factor is related to the fact that after the Second World War, the notion of command responsibility was in its infancy and a broad notion of what constitutes knowledge was applied, resulting in a doctrine, which was considered too large a circle to be applied to such perpetrators. ${ }^{105}$ Secondly, the evidence available in especially German and Japanese military cases was primarily based on documents, which made it easier to impute the various aspects of commander liability, such as control, knowledge and measures to prevent or punish.

This situation changed when the ICTY and ICTR entered the picture of international justice. The law of command responsibility became the subject of more scrutiny by their judges with as a result that the some of the requirements became the subject of a higher or least more detailed threshold, especially for non-military cases. Combined with less availability of documentary evidence and necessarily more reliance on insider witnesses or technological evidence (which became more crucial but harder to obtain, especially

104 Decision on the Confirmation of Charges, Lubanga (ICC-01/04-01/06), Pre-Trial Chamber I, 29 January 2007, $\$ \$ 349-350$; Decision of the Confirmation of the Charges, Katanga and Chui (ICC No. ICC-01/04-01/07), Pre-Trial Chamber I, 30 September 2008, \$\$ 527-528, 533-534 and 538-539; Decision of Confirmation of Charges, Bemba (ICC-01/05-01/08), Pre-Trial Chamber II, 15 June 2009, § 351; Decision of the Confirmation of the Charges, Garda (ICC-02/05-02/09), Pre-Trial Chamber I, 8 February 2010, $\$ 161$; Corrigendum of the Decision on the Confirmation of Charges, Nourain and Jamus, (ICC-02/05-03/09), Pre-Trial Chamber I, 7 March 2011, \$\$ 150-153; Decision on the Prosecutor's Application for Summonses to Appear for Francis Kirimi Muthaura, Uhuru Muigai Kenyatta and Mohammed Hussein Ali (CC-01/09-02/11), Pre-Trial Chamber II, 8 March 2011, $\$ 36$; Decision on the Prosecutor's Application for Summons to Appear for William Samoei Ruto, Henry Kiprono Kosgey and Joshua Arap Sang (ICC-01/0901/11), Pre-Trial Chamber II, 8 March 2011, $\$ 40$; Decision on the Confirmation of Charges, Francis Kirimi Muthaura, Uhuru Muigai Kenyatta and Mohammed Hussein Ali (CC-01/0902/11), Pre-Trial Chamber II, 23 January 2012, \$296-297; Decision on the Confirmation of Charges, William Samoei Ruto, Henry Kiprono Kosgey and Joshua Arap Sang (ICC-01/09-01/11), Pre-Trial Chamber II, 23 January 2012, $\$ \$ 286-292$, 306, 313, 333-336, 348; Judgment, Lubanga (ICC-01/04-01/06), Trial Chamber, 14 March 2012, $\$ 1012-1013$.

Ambos 2013, op. cit., pp. 108-109. 
for the knowledge aspect) some cases, which exclusively used this theory of the case, were not successful. ${ }^{106}$ For that reason, the JCE doctrine became more attractive to prosecutors.

While JCE had its origin in the concentration camp cases after the Second World War, it came in full bloom especially at the ICTY, followed by the ICTR and then the SLSC. Over time some manifestations to its application were adjusted by the judiciary of these institutions, most likely as a result of academic criticism and arguments by defence counsel; especially JCE III was seen as problematic in this context, which could account for the fact that it is not part of the ICC equivalent of JCE, namely common purpose in article $25.3(\mathrm{~d}){ }^{107}$

With respect to perpetration, not only is this form of liability controversial in international criminal law in general, ${ }^{108}$ its parameters are uncertain at the moment as a result of disagreement between ICC trial judges themselves. It is hoped that the ICC Appeals Chamber, which heard the appeal in the Lubanga case on May 19-20, 2014, will at least resolve the latter issue.

\section{Conclusion}

International criminal law as a pursuit of global justice has changed over the last 20 years. Originally, the main actors in this arena were either an international or hybrid tribunals but the situation has changed.

Now that a large number of domestic players have entered the international justice arena there is a risk of unbridled and uncontrolled diversity. In itself diversity at the local level is not problematic since international law can and should take into account local conditions and customs. In addition, given the fact that international law still finds a

106 See for instance, Judgment, Halilović (IT-01-48-A), Appeals Chamber, 16 October 2007.

107 Van Sliedregt 2012, op. cit., pp. 146-147; Lafontaine, Prosecuting Genocide, Crimes against Humanity and War Crimes in Canadian Courts (Carswell, 2012) p. 241; Ambos 2013, op.cit., pp. 1272-1273; Cryer et. al., op.cit. at note 51, p. 363; see also Judgment, Chui, Concurring Opinion of Judge Christine Van den Wyngaert (ICC-01/04-02/12), Trial Chamber, 18 December 2012, § 61 , footnote 77.

108 Perpetration was rejected by a majority of judges of Appeals Chamber of the ICTY/ICTR in Judgment, Stakić (IT-97-24-A), Appeals Chamber, 22 March 2006, \$\$ 58-63; Separate Opinion of Judge Shahabuddeen in Judgment, Gacumbitsi, (ICTR-2001-64-A), Appeals Chamber, 7 July 2006, $\$ \$ 42-52$; Separate Opinion of Judge Schomburg on the Criminal Responsibility of the Appellant for Committing Genocide in Judgment, Gacumbitsi, (ICTR-2001-64-A), Appeals Chamber, 7 July 2006, $\$ \$ 17-27$; Dissenting Opinion of Judge Schomburg in Judgment, Simić (IT-95-9-A), Appeals Chamber, 28 November 2006, \$\$ 11-21; Judgment, Prlić et al. (IT-04-74), Trial Chamber, 29 May 2013, \$210; Judgment, Đorđević (IT-05-87/1-A), Appeals Chamber, 27 January 2014, $\$ \$ 63-65$; see also Special Tribunal for Lebanon, Interlocutory Decision on the Applicable Law: Terrorism, Conspiracy, Homicide, Perpetration, Cumulative charging, STL-IIOI/I/AC/RI76bis, Appeals Chamber, 16 February 2011, $₫ 256$ 
great deal of its sources in domestic practice ${ }^{109}$ eventually these state practices will have an effect on international law and therefore international institutions, especially in international criminal law where little state practice is required to create a new custom. ${ }^{110}$ But this strong relationship between individual state practice and international custom in international criminal law creates an equally strong responsibility for states, now that they are engaging in this area of law, to ensure that they adhere to the basic principles of international criminal law as developed by the international institutions while still retaining the ability to infuse such principles with local content. This process is beginning as some recent jurisprudence in Argentina ${ }^{111}$ and Canada has shown. ${ }^{112}$

On the other hand, there is an equally important responsibility on the part of the international institutions to provide consistent legal guidance to national institutions when they engage in international criminal prosecutions. This guidance, in so far as it pertains to the most relevant form of extended liability, has not been forthcoming as of yet at the international level although the possibility exists that some of the divergent practices can be reined in.

Finally, the present reality that most cases of both high and low level perpetrators have been successfully prosecuted in countries operating on the basis of territorial jurisdiction suggests that there could be a better division of labour between the various international and domestic institutions. Such a division of labour would be based on a dual complementarity approach. At the first level states with an ability to carry out meaningful prosecutions for war crimes, crimes against humanity and genocide should be responsible for doing so for crimes committed on their territory or by their nationals. Persons, who have fled such countries, should be returned there either by employing the means of extradition or immigration remedies such as deportation. If a prosecution in such a country is not possible and a perpetrator is present in another country the latter should rely on either passive or universal jurisdiction to take action against that perpetrator. At the highest level, i.e. when the other two avenues are not possible the ICC (being most likely the only institution at the international level after 2017) could step in. countries ratify such treaties and in customary international law where states are still a very important direct source of law.

110 See Van der Wilt, National Law: A Small but Neat Utensil in the Toolbox of International Criminal Tribunals, 10 (2) International Criminal Law Review (2010), pp. 209-241.

111 See http://www.cij.gov.ar/nota-13255-Causa-ESMA--la-C-mara-Federal-de-Casaci-n-Penalconfirm--las-condenas-y-anul--las-absoluciones.html.

112 See Currie \& Rikhof 2013, op.cit., pp. 275-278. 